\title{
Anadolu Kırsalında Göçün Dünkü (XVI-XX. Yüzyll) Yapısı: Manisa ve Konya Çevresi Üzerinden Bir Göç Okuma Denemesi'
}

\section{ilker YiĞiT*}

\begin{abstract}
ÖZ
Göçler, tarihin hemen her döneminde toplumları siyasi, sosyal ve ekonomik açılardan etkileyen önemli faktörler arasında yer almaktadır. Öyle ki geçmiş dönemlerde göçler bir siyasi organizasyonun çökmesine neden olurken, başka bir siyasi organizasyonun hayat bulmasına yol açabilmiştir. Böylesine önemli etkileri olan göç olgusuna ilişkin ülkemizde yapılan çalışmalarda daha çok çağdaş dönem kapsamındakilere odaklanıldığ1 görülmektedir. Ancak bugünün doğru okunmasında ve geleceğe dair sağlıklı projeksiyonların yapılmasında tarihi göçlerin de ele alınması bir zorunluluktur. Özellikle yakın geçmişimiz olan Osmanlı Anadolu'sunun göç yapısının araştırılması, hem göçün tarihi arka planının ortaya çıkarılmasında hem de çağdaş göçleri bu tarihi tecrübe bağlamında değerlendirilmesinde ciddi katkılar sağlayabilecektir. Bu çalışma ile göç tarihine ilişkin literatüre, zaman olarak XVI. yüzyıldan XX. yüzyıla kadarki, mekân olarak ise Manisa ve Konya örnekleri üzerinden, Anadolu kırsalındaki göçlerin yapısı araştırılarak katkı yapılması hedeflenmiştir. Araştırmada temel olarak Osmanlı kırsalında meydana gelen göçlerin sebepleri nelerdir? sorusuna cevap aranmıştır. Bunun için arşiv vesikalarından, arazi araştırmalarından ve saha literatüründen elde edilen bilgi ve bulgulardan yararlanılmıştır. Araştırma sonucunda, çalışılan zaman dilimi ve örneklem sahaları dahilinde kırsalda yaşanan göçlerin doğal afetler, salgın hastalıklar, eşk1yalık faaliyetleri, vergi baskısı, ana ulaşım ağı üzerinde bulunmaya bağlı
\end{abstract}

1 Bu çalı̧sma Afyon Kocatepe Üniversitesi Sosyal Bilimler Enstitüsü Coğrafya ABD hazırlanmış olan XVI-XX. Yüzyıllarda Anadolu'da Kaybolan Yerleşmeler: Manisa-Konya Örneği başlıklı doktora tezinden üretilmiştir. Söz konusu tez yürütücülüğünü Prof. Dr. Osman GÜMÜŞÇÜ'nün yaptığ1 113K101 numaralı SOBAG/TÜBİTAK projesi tarafindan desteklenmiş olup bu teze verdiği destekten dolayı TÜBİTAK'a teşekkür ederim.

** Dr. Öğr. Üyesi, Burdur Mehmet Akif Ersoy Üniversitesi, Fen Edebiyat Fakültesi, Coğrafya Bölümü, Burdur/Türkiye

E-posta: iyigithg@gmail.com, ORCID: 0000-0002-1473-3438,DOI: 10.32704/erdem.572906

Makale Gönderim Tarihi: 12.11.2018 * Makale Kabul Tarihi: 24.05.2019 * (Araştırma Mk.) 
olarak ortaya çıkan huzursuzluklar gibi itici faktörler nedeniyle ortaya çıktı̆̆ tespit edilmiştir. Bazen bu itici faktörler bireysel göçlere neden olabildiği gibi toplu göçlere ya da kırsal iskân merkezlerinin yer değiştirmesine yol açabilmiştir. Yaşanan göçlerin kırdan şehre olabildiğgi gibi belki bundan daha fazla bir kısmı kırsalın kendi içerisinde cereyan ettiği anlaşılmaktadır. Arşiv vesikaları ve arazi araştırmalarından elde edilen bilgiler bu duruma dair önemli ipuçları olarak değerlendirilebilir. Çeşitli sebeplerle kırsalda meydana gelen göç hareketi şehirlerin yanı sıra merkezî, güvenli ve kalabalık köylere doğru gerçekleşmiştir. Başta ekonomik ve güvenlik faktörlerinin etkisiyle gerçekleşen kırsal alandaki göçler neticesinde kırsal iskân merkezleri yer yer toplulaşmıştır. Meydana gelen toplu göçler, bir taraftan bazı köylerin ortadan kalkmasına yol açarken diğer taraftanda mevcut köylerin devamlılı̆̆1na önemli katkılar sağlamıştır.

Anahtar kelimeler: Tarihi coğrafya, tarihi göç, tarihi demografi, kırsal göç, zorunlu göç. 


\section{ABSTRACT \\ The Structure of Migration Past in the Anatolian Countryside (XVI-XX. Century): An Essay to Read Migration via the Manisa and Konya Environment}

Migration is one of the important factors affecting societies in political, social and economic terms in almost every period of history. In the past, while the migration led to the collapse of a political organization, it led to the emergence of another political organization. However, it is a necessity to consider the historical migrations in order to make a correct interpretation of today and to make healthy projections about the future. In particular, the investigation of the migration structure of Ottoman Anatolia, which is a recent history, will be able to provide significant contributions both in revealing the historical background of migration and in the evaluation of contemporary migrations in the context of this historical experience. The aim of this study is to contribute to the literature on the history of migration, as time from the sixteenth century to the twentieth century, as investigating the structure of migrations in Anatolian countryside through the samples of Manisa and Konya. In the study, basically the following question was sought: What are the reasons for the migration in the Ottoman countryside? For this purpose, information and findings obtained from archive documents, field surveys and field literature were used. As a result of the research, it has been determined that the migrations in rural areas within the time frame and sampling areas are caused by the pushing factors such as natural disasters, epidemics, banditry activities, tax pressure, and unrest in the main transportation network. Sometimes these pushing factors could lead to individual migration, as well as to mass migration or displacement of rural resettlement centers. It is understood that the migrations may occur from rural to urban areas, and more than this, some of which occured within the countryside itself. Information obtained from archival documents and field surveys can be considered as important clues to this situation. The migration movement that took place in the countryside due to various reasons was realized towards the central, safe and crowded villages as well as the cities. As a result of migrations in rural areas, which were mainly due to economic and security factors, rural resettlement centers conglomerate. On the one hand, the mass migrations caused some villages to disappear and on the other hand, they made significant contributions to the continuity of the existing villages.

Keywords: Historical geography, historical migration, historical demography, rural migration, forced migration. 


\section{Giriş}

Tsa bir tanımlama ile bir yerden başka bir yere hareket olarak ifade edi\lebilen göç, sadece insanların sayı bakımından bir mekândan diğerine aktarımından ibaret bir olay değildir. Çünkü göç eden insan beraberinde pek çok şeyi gittiği sahaya taşımaktadır. Bu haliyle göç, nüfus hareketinin yanında sermayenin, bilginin, deneyimin, işgücünün, kültürün, üretim ve tüketim kalıplarının, hayat tarzının ve hatta hastalıkların kısaca yaşamın her alanına dair bir değişimin ve hareketin adı olmaktadır (Yakar, 2009: 40). Hatta göç işgücünü, üretimi daha etkin kılacak şekilde yeniden dağıtılarak, mekân organizasyonunun yeni koşullara uyumunu sağlamaktadır (Tekeli, 2008a: 18).

Göç, iki farklı nokta arasında yer değiştirmeyi içeren mekân ve bu hareketi gerçekleştiren insan olmak üzere iki temel unsura sahiptir. İnsanlar, mekânsal özellikleri değerlendirdikten sonra bunun sonucuna göre yer değiştirmeyi ya da bulunduğu yerde kalmayı tercih etmektedir. Bu pencereden bakıldığında göç hadisesi oldukça genel prensiplere ve basit bir işleyişe sahip gibi görünse de nedenleri ve sonuçları itibariyle oldukça karmaşı bir yapıya sahiptir (Yakar, 2009: 1). Bu nedenle göçün sebepleri ve işleyiş mekânizmasına dair yapılan araştırmalar neticesinde çeşitli kuramlar öne sürülerek izah edilmeye çalışılmıştır (Çağlayan, 2006; Tekeli, 2008a; Yakar, 2009: 34). Çalışmayı yapan kişinin tercihine kalan bu durumu Osmanlı döneminde meydana gelen göçler için de göz önünde bulundurmak mümkündür. Osmanlılar zamanında meydana gelen göçler, Lee tarafindan 1966 yılında ortaya konulan (Çağlayan, 2009: 72-73) itici ve çekici faktörler çerçevesinde ele alınabilir. Zira insanların yaşadıkları bölgelerden ayrılarak göç etme nedenleri çeşitli olduğu gibi gittiği yerdeki cazibe unsurları da farklılık arz edebilmektedir. Geçmiş dönemde insanların yerlerini terk etmesi, ekonomik açıdan zor durumda olma, eşkıya baskısı, doğal afetler, salgın hastalıklar, devlet görevlilerinin, ayanların vs. güç sahibi kişilerin baskı ve zulümleri gibi sebeplerle ilişkili olduğu rahatlıkla ifade edilebilir. Çekici unsurlar arasında ise ekonomik ve sosyal açıdan daha güvenli ve iyi imkânlara sahip olmak, vergi yükünden kurtulmak ve itici faktörlerin tamamının veya bir kısmının olumluya dönüşeceğini ümit ettiği bir sahada yaşama isteği olarak belirtilebilir.

Göçler gerek Türk tarihinde ve gerekse dünya tarihinde oldukça yaygın olarak görülen bir husustur. Dünya tarihini derinden etkileyen göçlerin yanı sıra ülke sınırları içerisinde meydana gelen göç hareketleri hiç şüphesiz siyasi, sosyal ve ekonomik hayat açısından geçmişte ve günümüzde oldukça önemli bir yer işgal etmektedir. Nitekim Kemal Karpat (2015: XXXIX) göçün Türkiye tarihi açısından önemini şu sözlerle ifade etmiştir: "Türkiye, göçler sayesinde kurulmuş, değişmiş ve bugün milli devlet haline gelmiştir”. Gerçekten de bugünün Türkiye'sini anlamak ve anlamlandırmak için geçmişin ve hususiyle 
de göç tarihinin bilinmesi gerekmektedir. Bu hem bugünkü göç çalışmalarına farklı bir bakış açısı sağlayacak hem de göçün tarihselliğinin doğru bir şekilde ortaya çıkarılması ile bugünün ve yarının planlanmasında, göçe dair stratejiler geliştirilmesinde bir temel oluşturacaktır.

Farklı disiplinlere mensup araştırmacılar tarafindan tarihi kaynaklar kullanılarak son zamanlarda göç konusuna ilişkin çeşitli bilimsel toplantıların² ve çalışmaların ${ }^{3}$ gerçekleştirildiği dikkati çekmektedir (Gümüş̧̧ü vd. 2016:

2 Bilimsel toplantılara örnek olarak Samsun'da yedincisi 17-19 Şubat 2017 tarihinde düzenlenen "Geçmişten Günümüze Göç VII. Uluslararası Canik Sempozyumu" örnek verilebilir.

3 Bu çalışmalardan bazılarını burada belirtmekte fayda vardır: Münir Aktepe, 1958. “XVIII. Asrın İlk Yarısında İstanbul'un Nüfus Meselesine Dair Bazı Vesikalar", İstanbul Üniversitesi Edebiyat Fakültesi Tarih Dergisi, IX/13, s. 1-30; Yücel Özkaya, 19811982. "Osmanlı İmparatorluğu'nda XVIII. Yüzyılda Göç Sorunu”, Ankara Üniversitesi Dil ve Tarih-Coğrafya Fakültesi Tarih Araştırmaları Dergisi, C. XIV, Sayı 25, s. 171211; Nedim İpek, 1991. “Kafkaslar'dan Anadolu'ya Göçler (1877-1900)”, Ondokuz Mayls Üniversitesi Ĕgitim Fakültesi Dergisi, Sayı 6, s. 97-134; Nedim İpek, 1991. "Kafkaslardaki Nüfus Hareketleri”, Türkiyat Mecmuası, Sayı 20, s. 273-313; Suraiya Faroqhi, 1998. "Migration into Eighteenth-Century Greater İstanbul as Reflected in the Kadi Registers of Eyüp", Turcica, 30, s. 163-183; Nedim İpek, 1999. Rumeli'den Anadolu'ya Türk Göçleri, Türk Tarih Kurumu Yayınları, Ankara; İbrahim Güler, 2000. “XVIII. Yüzyılda Osmanlı Devleti’nde Nüfus Hareketleri Olarak İç Göçler”, İstanbul Üniversitesi Edebiyat Fakültesi Tarih Dergisi, 1995-2000 Prof. Dr. Fikret Işlltan Hatıra Saylst, Sayı: 36, s. 155-211; Hüseyin Arslan, 2001. 16. Yüzyll Osmanlı Toplumunda Yönetim, Nüfus, İskan, Göç ve Sürgün, Kaknüs Yayınları, İstanbul; Osman Gümüşçü, 2004. "Internal Migrations in Sixteenth Century Anatolia", Journal of Historical Geography, 30/2, s. 231-248; Nedim İpek, 2006. İmparatorluktan Ulus Devlete Göçler, Sarender Yayınları, Trabzon; Cengiz Şeker, 2007. İstanbul Ahkam ve Atik Şikayet Defterlerine Göre 18. Yüzyılda İstanbul'a Yönelik Göçlerin Tasvir ve Tahlili, Marmara Üniversitesi Sosyal Bilimler Enstitüsü, İstanbul (Basılmamış YL Tezi); Alpaslan Demir, 2009. "16. Yüzyılın İlk yarısında Diyarbakır Şehir Demografisine Göçlerin Etkisi”, Bilig, Sayı 50, s. 15-28; Alpaslan Demir, 2011. "XVI. Yüzyıl Anadolu'sunda Dış Göçler: Şarkiyan”, Karadeniz Araştırmaları, S. 28, s. 51-66; Mehmet Demirtaş, 2011. "Osmanlıya Gelen Kırım ve Kafkasya Göçmenlerinin Sorunları”, Bilig, Sayı 57, s. 17-44; Nedim İpek, 2014. "Kaynakların Dilinde Göç Kavramı", Karadeniz İncelemeleri Dergisi, Sayı 17, s. 9-20; "Justin McCharty, 2014. Ölüm ve Sürgün, Türk Tarih Kurumu Yayınlar1, Ankara; Mehmet Demirtaş, 2017. "XIX. Yüzy1lda İstanbul'a Göçü Önlemek İçin Alınan Tedbirler: Men-i Mürûr Uygulaması ve Karşılaşılan Güçlükler”, Belleten, Cilt: LXXIIISay1: 268, s. 739-754; Emine Erdoğan Özünlü ve Osman Gümüşçü, 2016. “Osmanlı İmparatorluğu'nda İç Göç Aktörleri Olarak Çift-Bozanlar”, Amme İdaresi Dergisi, Cilt, 49, Sayı, 1, s. 29-56; Mehmet Demirtaş, 2017. "XIX. Yüzy1lın İlk Yarısında İstanbul'da Kamu Düzenini Bozan Gruplara Karşı Yürütülen Mücadele”, Belleten, Cilt:LXXXISayı:291, s. 481-524. İlker Yiğit, 2018. "Tarihi Göç Çalışmalarında Bir Veri Kaynağ1 Olarak Mezar Taşları", XVIII. Türk Tarih Kongresi 01.10.2018 -05.10.2018, Ankara; İlker Yiğit, 2018. "Tarihi Göç Çalı̧̧malarında Osmanlı Dönemi İstatistiki Kaynakları", TÜCAUM 30. Yıl Uluslararası Coğrafya Seтроzуumu 03.10.2018 -06.10.2018, Ankara, s. 641-650. 
429). Böylece giderek artan sayıda göç çalışması özellikle Osmanlı dönemi için bilim dünyasına kazandırılmaktadır.

Bölgeden bölgeye ve zamandan zamana değişebilen itici ve çekici faktörlerin etkisiyle Osmanlı döneminde bulunduğu mekândan halkın ayrılması yasak olmasına (Barkan, 1950: 545) rağmen göç sürekli yaşanmıştır. Devlet, ideal sisteminin işleyiş mekânizmasının bozulmaması, herkesin yerli yerinde üzerine düşen görev ve yükümlülükleri ifa etmesi için gayret sarf etmiştir. $\mathrm{Bu}$ ideal düzenin korunması ve sürdürülebilmesi için devlet kendi kontrolü dışındaki göç olaylarını engellemeye çalışmıştır. Zira Osmanlı Devleti idari ve mali sistemi toplumsal sinıfları kendi mesleklerine ve görevlerine bağlama amacı güdüyordu. Temel bir prensip olarak çocukların, babalarının mesleğini devam ettirmeleri esastı. Özellikle de kırsal alanda köylerde yaşayan köylülerin toprağını terk ederek başka yerlerde iş tutması istenen bir durum değildi ve yasaktı (Tabakoğlu, 1999: 26-27). Devletin kendi tasarrufu (sürgün, konar-göçerlerin ve muhacirlerin iskânı gibi hususlar [Karpat, 2010: 90-96]) dışındaki nüfus hareketlerini önlemek için koymuş olduğu yasalar ve caydırıcı birtakım tedbirlere rağmen aşağıda görüleceği üzere uygulamada bunlar tam manasıyla etkili olmamıştır/olamamıştır. Başka bir ifadeyle Osmanlı ülkesi dahilinde insanlar bir şekilde göç ederek ideal sistem öğretisinin dikte ettiğinin ötesine geçmiştir. Bu yönüyle Osmanlı ülkesi ve özelde Anadolu nüfus çeken, nüfus gönderen ve kendi içerisinde demografik bir dinamizme sahip "göçler coğrafyası" olarak nitelenebilir.

Ekonomik faktörlere bağlı olarak kırsal alandan şehirlere gerçekleşen göç olgusu Osmanlı döneminin olağan ve önemli bir özelliği durumundadır. İşçiler ailesini almadan oldukça uzak mesafelerdeki şehirlere giderek belirli bir süre çalıştıktan sonra tekrar memleketlerine geri dönerlerdi (Quataert, 2002: 177). Osmanlı döneminde kırsal alanlardan şehirlere olan göçe $F$. Braudel şu cümle ile dikkati çekmiştir (Braudel, 1993: 406; Gümüşçü vd., 2016: 438): "Osmanlı imparatorluğunun bütününde, devletin denetim ve yasaklarıyla, esnaf kuruluşlarının şüphe duymalarına rağmen, hiçbir kent yoktur ki, talihsiz veya aşırı nüfuslu kırlardan kesintisiz olarak göçmen kabul etmesin”. Braudel tarafindan ifade edilen bu husus, özellikle XVI. yüzyılda göç üzerine çalışmalar gerçekleştiren araştırmacılar tarafindan kanıtlanmış durumdadır. Barkan ve Meriçli tarafindan XVI. yüzyıl Bursa kazası Kapluca kasabasında meskûn 107 haneden 13'ü; Bursa şehri Simaviyan mahallesinde meskûn 73 haneden 20'si göçmendir (Barkan ve Meriçli, 1988: 8-254). Ayntab şehrinde 1536'da 1.856 neferden 147'si (Özdeğer, 1988: 115-116), Larende şehrinde 1584'te 2.048 neferden 178'i (Gümüşçü, 2001: 167-182), Tokat şehrinde 1554'te 3.227 neferden 338 'i, Sivas şehrinde 1554'te 2.380 neferden 144'ü (Demir, 
2007: 211-213), göçmendir (Gümüşçü vd., 2016: 440-442). Göç olayı Osmanlı sisteminin tam teşekkül ettiği ve araştırmacılar tarafından klasik dönem olarak isimlendirilen bir devirde (XVI. yüzyılda) Osmanlı ülkesinin açık seçik bir realitesidir.

Osmanlı döneminde gerçekleşen göçlere doğrudan atıf yapan birtakım veriler bulabilmenin imkânı yanında dolaylı bir şekilde göçün varlığına işaret eden hususları da görmek ihtimal dahilindedir. Bu noktada yerini yurdunu terk ederek üretim yapmayan insanlardan alınan "çift-bozan vergisi” dolaylı göç verisi olarak değerlendirilebilir. Osmanlılar zamanında şayet bir kişi meskûn olduğu yerdeki araziyi terk edip başka bir yere giderek hayatını kazanmaya başlar ise çift-bozan resmi vermek mecburiyetindeydi (Çağatay, 1947: 501). Kanunnamelerde yer aldığı üzere köylü ahali başka bir yere gitmiş ve yerleşmiş ise timarlı sipahi ilgili köylüleri eski yerlerine getirme hakkına sahipti. Eyaletten eyalete değişmekle birlikte göç eden köylüyü 10-15 sene içerisinde tekrar köyüne döndürme hakkı bazı yerlerde 20 yıla kadar çıkabiliyordu. Ĕger köylü göç ettiği mekâna döndürülmede zorlanmaz ise bu durumda köylü timarlı sipahiye "leventlik akçesi” ya da "çiftbozan akçesi" olarak isimlendirilen vergiyi ödemek mecburiyetindeydi (Barkan, 1950: 44-48; Faroqhi, 1993: 329). Çift-bozan vergisinin alınması Osmanlı Devleti'nin temel yapı taşlarından biri olan timar sisteminin sağlıklı ve etkin bir işletilmesinin sürdürülebilirliği amacıyla uygulanan bir yaptırımdır. Timar sistemi bir taraftan asker temininin diğer taraftan da tarımsal üretimin ve vergilendirmenin devamı için önem taşıyordu. Kurulan bu düzenin sürdürülebilmesi için birtakım yaptırımlar kaçınılmaz oluyordu ki çift-bozan vergisi bu cezai müeyyidelerden birisi olarak değerlendirilebilir (Erdoğan Özünlü ve Gümüşçü, 2016: 35; Gümüşçü vd., 2016: 430).

Mazeretsiz olarak toprağını boş bırakan ve başka bir yere giden köylüden alınan çift-bozan vergisinin (Genç, 2007: 526) miktarı XV. yüzyılda Fatih Kanunnamesinde 50 akçe iken XVI. yüzyılın sonuna gelindiğinde 300 akçeye çıkmıştır (Erdoğan Özünlü ve Gümüşüü, 2016: 41). Çift-bozan resmi ve leventlik akçesi isimli bu vergiler Tanzimat ile birlikte yürürlükten kaldırılmıştır (Pakalın, 1993: C. III: 30). Söz konusu verginin mevcudiyeti ve XVI. yüzyılın sonunda 300 akçeye kadar çıkması ülke sathında göçün oldukça yaygın olduğunun bir kanıtı olsa gerektir. Ceza miktarının artırılarak göçe yönelen insanların engellenmesi amaçlanmıştır. Ancak her ne kadar cezalar artırılsa da göç önlenememiştir.

Farklı sahalarda göçler meydana gelmekle birlikte Osmanlı ülkesi içerisinde en fazla göç olayının gerçekleştiği merkezlerin başında İstanbul gelmektedir. 
İstanbul'un alınmasının ardından Osmanlı Devleti fetih ve iskân politikasının bir neticesi olarak kısa sürede şehrin nüfusunda hızlı bir artış görülmüştür (Faroqhi, 2016: 461; Gümüşçü vd., 2016: 433). Özellikle XVI. yüzy1lın ikinci yarısına gelindiğinde devam eden göç dalgaları, şehirde birtakım olumsuzlukların yaşanması ve geldikleri yerlerde nüfus azalmasına bağlı ortaya ç1kan problemler neticesinde demografik hareketliliğe karşı hükümet birtakım önlemler almak zorunda kalmıştır (Refik [Altınay], 1987: 205-206). Celâli isyanlarının tahrikiyle özellikle de "büyük kaçgunluk" devrinde (1603-1608) (Akdağ, 1964: 1-51; Akdağ, 1999: 455) kırsaldan şehirlere yaşanan göçten İstanbul da büyük ölçüde etkilenmiştir. İstanbul şehrine giremeyenler Silivri, Ereğli, Küçük Çekmece ve Büyük Çekmece çevrelerinde çiftliklerde hizmetçi olarak yaşamlarına devam etmişlerdir. İstanbul ve mücavir alanına göç eden kişileri geri göndermek için XVI. yüzyıl sonlarına değin zaman aşımı süresi 5, 10, 15 yıl iken XVII. yüzyılda bu süre 20 yıla çıarılmıştır. Hatta IV. Murad zamanında bu sürenin 40 yıla çıkarılması problemin büyüklüğünü ve devam ettiğini göstermesi açısından dikkate değer bir durumdur (Gümüşçü vd., 2016: 436; Mete, 2011: 69-74).

Osmanlı ülkesinde her şeye rağmen devam ettiği anlaşılan nüfus hareketleri bağlamında eldeki bu çalışmada Manisa ve Konya çevresi örneklemlerinde, XVI-XX. yüzyıllarda meydana gelen göçler ele alınmıştır. İki farklı alan üzerinden konun ele alınması her şeyden önce bölgesel farklılığın yansıtılmasıdır. Zira bölgeden bölgeye değişen fiziki ve beşeri coğrafya koşulları göçün nedenlerini farklılaştırabilmektedir. Örneğin Manisa çevresinde deprem, taşkın, Konya çevresinde ise kuraklık bir göç nedeni olarak karşımıza çıkabilmektedir. Ayrıca iki saha için çeşitli arşiv vesikalarının uzun dönemleri kapsayacak şekilde (tahrir defteri, şer'iye sicilleri gibi) mevcudiyeti diğer bir tercih sebebidir.

Çalışma boyunca Osmanlı kırsalında meydana gelen göçlerin sebepleri nelerdir? sorusuna cevap aranmıştır. Bu temel soruya cevap bulabilmek için arşivden, arazi çalı̧̧malarından ve literatürden elde edilen verilerden faydalanılmıştır. Eldeki çalışma bir tarihi coğrafya çalı̧̧ması olduğu için hem tarih hem de coğrafyanın yöntem ve teknikleri kullanılmıştır. Manisa ve Konya özelinde elde edilen bulgular hiç şüphesiz Osmanlı Anadolu'sunun göç yapısının okunmasına bir perspektif sağlayacaktır. En azından Anadolu kırsalındaki büyük göç resminin küçük bir parçası, mevcut bilgi ve bulgular çerçevesinde bir miktarda olsa görülebilecektir. Çalışmanın bu noktadaki temel argümanı farklı kaynaklar kullanılarak XVI yüzyıldan XX. yüzyıla değin kırsaldaki göçün yapısının temel karakteristiklerinin ortaya konulmasıdır. Bu yönüyle çalı̧̧ma, kırsalda yaşanan göçlerin temel nedenlerine ilişkin oldukça uzun bir 
zaman diliminde bir kavramsallaştırma çabasının sonucudur. Araştırılan zaman dilimi ve örneklem sahaları dahilinde kırsalda yaşanan göçlerin doğal afetler, salgın hastalıklar, eşkıyalık faaliyetleri, vergi baskısı gibi itici faktörlere bağlı olarak ortaya çıktığı tespit edilmiştir. Bazen bu itici faktörler bireysel göçlere neden olabildiği gibi toplu göçlere ya da kırsal iskân merkezlerinin yer değiştirmesine yol açabilmiştir.

\section{Manisa ve Konya Çevrelerinde Göç}

Osmanlı döneminde dış göçlerin yanı sıra Anadolu'da kırdan-ş̧ehire, kırdankıra, şehirden-şehire ve şehirden kıra olmak üzere iç göçler de yaşanmıştır. Her ne kadar sistem bireylerin kendi başına buyruk yer değiştirmesini yasaklamış olsa da göç bu topraklarda ve ilgili dönemde hep var olmuştur. Gerek yapılan çalışmalar ve gerekse arşiv vesikalarında yaşanan göçlere ve etkilerine ilişkin veriler bulmak mümkündür. Hatta arşiv vesikalarının dışında yapılan arazi çalışmaları sırasında gerçekleştirilen görüşmeler de kırsalda bir köyden diğer köye gerçekleşen göçler ve sebepleri ile ilgili önemli ipuçlarına ulaşmak imkân dahilindedir.

XVI. yüzyıldan itibaren Osmanlı ülkesinde ortaya çıkan göçlerde ekonomik siyasi nedenlerin belirleyici olduğu görülmektedir (Karpat, 2003: 4, 15). Nitekim araştırma alanlarımızda XVI. yüzyıl içerisinde tahrir defterlerine yansıyan birtakım göç verileri bulunmaktadır. Örneğin Manisa çevresinde (XVI. yüzyıl Manisa kazası) XVI. yüzyıl göçlerine ilişkin tahrir defterlerinde birtakım bilgiler yer almaktadır. Katibin titizliği sayesinde ulaşılabilen bu tesadüfi veriler $^{4}$ dönem göçleri ve yönü hakkında fikir sahibi olmamızı sağlamaktadır. Manisa çevresine ait tahrir defterlerinde yer alan bilgilere göre XVI. yüzy1l içerisinde Manisa şehrine 18 nefer göç etmiştir. Şehre göç edenlerin dişında Manisa kazası dahilinde 187 göçmenin bulunduğu görülür. Bu göçmenlerin çıkış yerlerine bakıldığında 71 köy, 10 şehir, kaza ve nahiyeden kaynaklandığ1 anlaş1lmaktadır (Gümüşçü vd., 2016: 355). Önemli yolların geçiş güzergâhında bulunan araştırma alanlarımızdan Konya çevresinde de önemli demografik hareketlilikler meydana gelmiştir. XVI. yüzyıla ait son mufassal tahrir defterindeki kayıtlara göre Konya çevresinde 129 göçmen vardır. Bu göçmenlerden 21’i Konya'dan dişarıya göç etmiştir. 55 kişi Konya çevresine diğer kaza ve sancaklardan gelmiş olup geriye kalanlar ise (53 kişi) kaza dahilinde göç etmişlerdir (TK KKA 104).

4 Tahrir defterlerinin tarihi coğrafya araştırmasındaki önemi ve bu defterlerde yer alan verilerin tasnifi hakkında bakınız. Osman Gümüşçü, 2008. "The Ottoman Tahrir Defters as a Source for Historical Geography”, Belleten, Say1: 265, s. 911-941 
Araştırma alanlarının hem yakın çevresinden hem de uzak bölgelerden gelen konar-göçerlerin göçüne de sahne olduğu görülmektedir. Nitekim Manisa çevresi kendi kırsalının dışında Anadolu'nun muhtelif bölgelerinde yaşayan konar-göçer grupların da göç için tercih ettiği bir yer olmuştur. Sahanın verimli toprakları, müsait iklim şartları ve ticari faaliyetlerin bölgede canlılığ insanları buralara çeken hususlar arasında olmalıdır. Manisa Şer'iye Sicilleri’ne yansıyan bir hüküm Batı Anadolu çevresinin göç çekim kabiliyetini açıkça göstermektedir. 1610 tarihli kayda göre, Anadolu, Maraş, Sivas, Erzurum ve Halep eyaletlerinden kalkıp Manisa çevresinde, Gemlik, Sakız ve Midilli'de 10 seneden az süredir serseri gezenler ve yerleşmiş olan konar-göçerlerin ellerindeki emlakin ve arazinin sattırılarak kadim yerlerine döndürülmesi istenmektedir (Gökçen, 1946: 81-82). Bu kayıt açık bir şekilde Anadolu'nun doğusundan, güneyinden ve ortalarından göç etmeye karar kılanlar için Manisa çevresinin cazip merkezler arasında olduğunu göstermektedir. Hatta emlak ve arazi satın alanların mevcut olması bu sahaya kalıc1 olarak geldiklerini göstermesi açısından ayrıca önemlidir.

Konya çevresinde de oldukça kalabalık bir konar-göçer grup olan Atçekenler'in kendi kazalarının dışındaki nahiye ve kazalarda yaşadıkları kaydedilerek göçe dair dolaylı bilgi verilmiştir. Kendilerine ait idari ünitenin dışında yerleşen Atçekenler, araştırma alanımıza giren Konya nahiyelerinde de (XVI. yüzyil Sahra, Hatunsaray ve Sudiremi nahiyeleri) mevcuttur. Sahra nahiyesinde 1591 tahririnde 239, 1642 avarız sayımında 17, Sudiremi nahiyesinde 1581'de 15, 1642'de 10 nefer Atçeken göçmeni yaşamaktadır. Ayrıca Konya şehri mahallelerinde de Atçekenler'in bulunduğu görülür. Şehirde 1591 senesinde 435 nefer, 1642'de ise 396 nefer göçmen mevcuttur. Bu rakamlar 1584 tahririndeki Konya şehir nüfusuna olan oranına bakıldığında \%12'lik bir dilime karşılık gelmektedir. 1584 sayımında 123 mahalle sayısı olan şehirde 43 ayrı mahallede Atçekenler meskûndurlar. Mahallelerde farklı say1larda bulunan Atçekenler kimi mahallede 1 nefer, kimi mahallede 30-40 nefer şeklinde dağılış göstermektedir. 1642 avarız sayımında ise Atçekenlerin meskûn olduğu mahalle sayısı 43'ten 32'ye düşmüştür. Bu düşüşte daha önce şehre yerleşen Atçekenlerin artık şehirli nüfusa dahil olduğu ve Atçekenlik statüsünden ilgisinin tamamen kesildiği düşünülmektedir (Karadeniz, 1995: 179-184).

Ravenstein (1885) tarafından ifade edilen "göçler kademeli bir şekilde gerçekleşir" ilkesini (Çağlayan, 2009: 68-69) arşiv vesikalarında görmek mümkündür. İlk önce köyden bir diğer köye sonra da şehre ulaşan bir örnek Konya Şer'iye Sicilleri'ne yansımıştır. 3 Eylül 1741'te Malas karyesi sakinleri, Nehr-i Kafur mahallesinde oturan Hacı İbrahim'in dört y1l öncesine kadar Malas'ta 
oturduğunu bildirdikten sonra tekrar ilgili köye döndürülmesini talep etmişlerdir. Bunun üzerine Hacı İbrahim aslen Ladik köyünden olduğunu iki sene kadar Malas'ta oturduğunu ancak burada arazi ve emlakı olmadığ 1 için şehre göç ettiğini söylemiştir. Neticede İbrahim isimli şahsın Malas köyüne döndürülmesi talebi mahkemece reddedilmiştir (KŞS 55, 155/1). Bu örnek bir şekilde köyden kalkan kişinin/ailenin direkt olarak şehre gitmediğini ya da gidemediğini bunun yerine yakın ve ulaş1labilir olan bir köyü tercih ettiğini daha sonra da buradan şehre ulaştı̆̆ını göstermesi bakımından değerlidir (Harita 1).

\section{Harita 1. Konya Çevresinde Kademeli Göç Örneği}

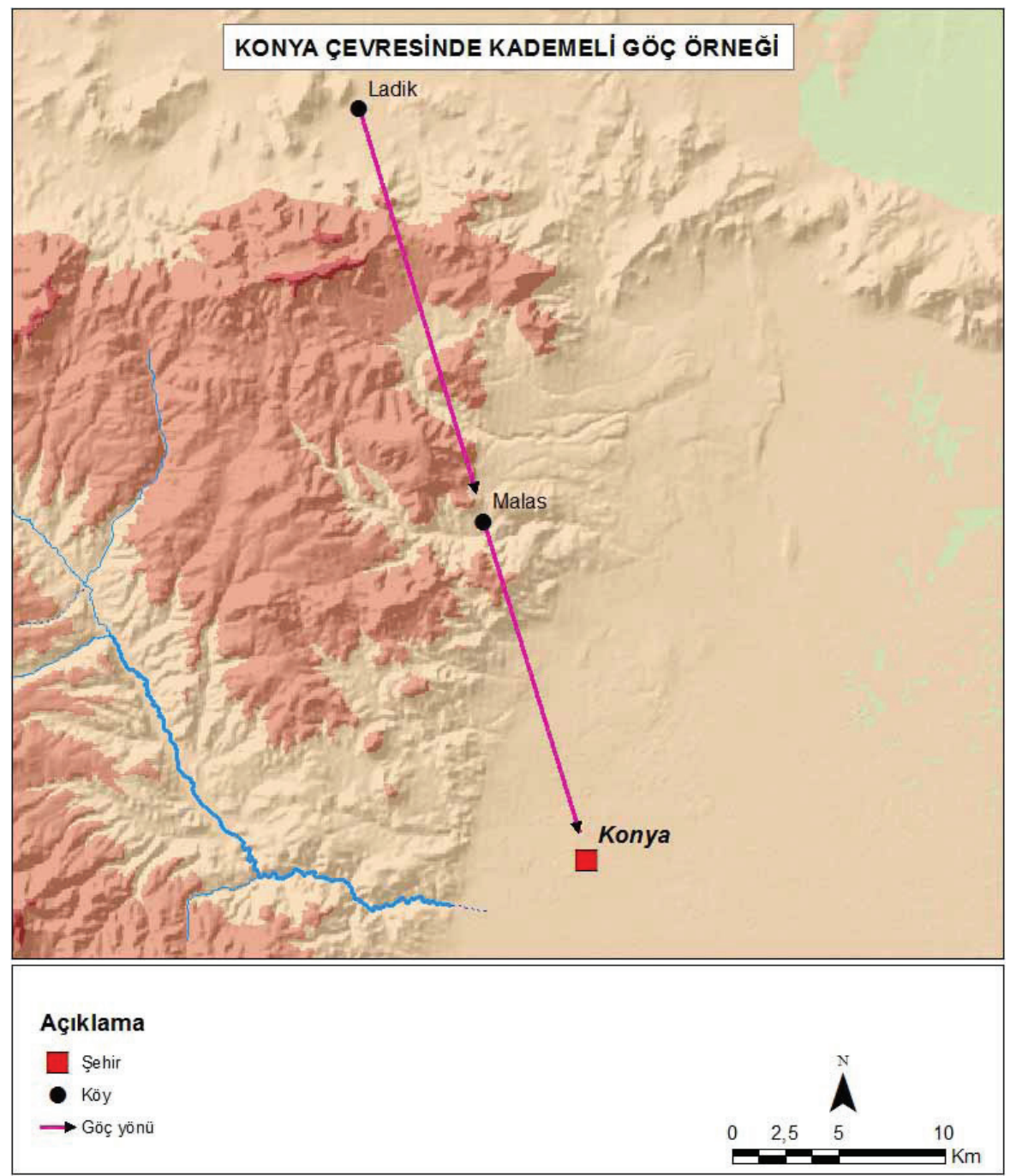


$\mathrm{Bu}$ çalışma kapsamında elde edilen ve aşağıda belirli kategoriler altında izah edilen nüfus hareketliliği büyük ölçüde zorunlu göçler olduğu dikkati çekmektedir. Bilindiği üzere tarım toplumlarında toprağa bağlı insanların yer değiştirmesi bireyin kendi iradesi ile olmamaktadır (Tekeli, 2008b: 42). Osmanlı Devleti de bu durumun istisnası değildir. Dolayısıyla tarım toplumunun egemen olduğu Osmanlı dönemindeki göçler de büyük ölçüde fiziki ve beşeri birtakım zorunluluklardan ortaya çıkmıştır. Ebetteki bunu ifade ederken bireylerin kendi arzu ve istekleriyle hiç göç etmediğini söylemek istemiyoruz. Ancak genellikle dönemin şartlarının bir sonucu olarak göçlerin daha çok zorunluluklar neticesinde cereyan ettiği görülmektedir.

İnsanların zorunlu olarak yer değiştirmesinin kaynağ $\dot{I}$. Tekeli (2008c: 141) tarafından üç farklı nedene bağlı olarak ifade edilmiştir. Bunlar 1) devletin belirli amaçlarını gerçekleştirmek, 2) savaşlar sonucunda yeniden uyum, 3) doğal afetlerin sonuçlarından kaçınmaktır. Tekeli tarafından Osmanlı dönemindeki bu göç kavramsallaştırmasının ötesinde ülke içerisinde zorunlu göçlerin oldukça farklı etkenlerle olabildiği ifade edilebilir. Zira bunlar devlet adamlarının kanun dışı hareketlerinden bir sahada ortaya çıkan doğal afetlere değin çeşitli gerekçeler olarak karşımıza çıkabilmektedir.

Verilen bu bilgilerden sonra XVI-XX. yüzyıl arası dönemde gerçekleşen göçün temel yapısına ilişkin elde edilen bulgulara geçilebilir. Aşağıda göçe sebep olan itici faktörler doğal afetler ve salgın hastalıklar, eşkıyalık faaliyetleri ve vergi baskısı başlıklarında ele alınarak değerlendirilmeye çalışılacaktır.

\section{1-Doğal afetler ve salgın hastalıklar}

Göç ve göç sürecini derinden etkileyen afet geniş anlamı ile canlı ve cansız çevreye zarar veren önemli ölçüde can ve mal kaybına neden olan sıra dışı, doğal ve beşeri olaylar şeklinde tanımlanabilir (Şahin ve Sipahioğlu, 2007: 5-13). Araştırmaya konu edilen zaman diliminde göçün yaşanmasına etkisi olduğu görülen bir dizi doğal afete ilişkin bazı bilgilere hem arazi araştırmaları hem de arşiv ve literatür vasıtasıyla ulaşılmıştır. Yaşanan doğal afetler insanların bireysel göçlerin ötesinde toptan göç etmelerine de neden olmuş görünmektedir.

Araştırılan zaman diliminde Manisa çevresinde depremlerin ön plana çıktı̆̆ı görülür. Özellikle XVI. yüzy1lda Manisa çevresinde meydana gelen depremler ciddi tahribatlara ve göçlere yol açmıştır. 22 Eylül 1595 yılında meydana gelen deprem belgelere şu şekilde yansımıştır: Deprem Gediz Nehri'nin aşağı kısımları boyunca bölgesel yıkıma neden olmuştur. Depremden Urganlı, Sart ve Seyyid Ahmedlü (Ahmetli) kasabaları ile Gedik, Bostancı, Hamza Çavuş, 
Azizlü ve Yapılu köyleri; Barçınlu köyünün yakınlarında, Ilıcak Nehri'nin kıvrıldığı kısımda yer yaklaşık 10 dönümden fazla (9400) yarılmış ve çıkan su bir minare yüksekliği kadar havaya fışkırmıştır... Görgü tanıklarının ifadesiyle yer, Manisa yolunda Gedüslü Köprüsü’ne kadar ikiye ayrılmı̧s ve katran gibi bir su çıkmıştır. Depremin ortaya çıkardığı hasar Akhisar'a kadar yayılmıştır (Ambraseys ve Finkel, 2006: 51). Manisa ile Gediz köprüsü arasında bir yarılmanın meydana geldiği ve katran gibi bir suyun fışkırdığ şeklindeki anlatılar depremselliğin insanlar üzerindeki etkisini göstermesi ve ilgili kırsalda yaşayan insanların göç etmesini sağlayabilecek hususlardan birisi olarak göz önünde bulundurulması bakımından dikkate değer bir durumdur (Yiğit, 2017: 337)

Geçmişte yaşanan sel ve taşkın olayları insanları yerinden eden faktörler arasındaki yerini almıştır.1575 yılında Gediz Nehri’nin taşmasıyla Manisa Büyük Kılcanlu köyü arazisi sular altında kalmıştır. Yaşanan bu taşkın felaketinde Gediz’in getirdiği çakıl ve kum Büyük Kılcanlu köyü tarım arazilerini kaplamış ve sahada tarım yapılamaz hale gelmiştir. Köydeki üretim 10 kat düşmüştür (TD 115, 39a; Emecen, 1989: 168). Azizlü, Yaylalu ve Derzilü köylerinin toprakları 1530 öncesinde sular altında kalarak 600 dönüm civarında arazi "sazlık ve kara suluk" hale gelmiştir. Yine aynı dönemde Göğezlü köyü Gediz taşkını sonucunda 30 çiftlik (1 çiftlik arazi iyi tarım alanlarında ortalama 60 dönüme karş1lık gelir) tarım arazisi 8 çiftliğe düşmüştür. Budakluca köyünde Gediz’in yatak değiştirmesi sonucu 200 dönüm arazi sular altında kalmıştır. 1530 yılına ait tahrir defterinde taşkın nedeniyle Köseörenlü köyü halkının bir kısmının Sinirlü bir kısmının da Çaparıca köyüne göç ettiği görülmektedir (BOA TD 165: 66-67; Yiğit, 2017: 339).

Tarihî süreçte Manisa havalisinde Gediz, Kumçayı ve Nif akarsularının aşırı sağanak yağışlara bağlı olarak XIX. yüzyılda da taşkınlar yaptığı görülmektedir. Nitekim 1850-1900 yılları arasında Gediz, Nif ve Kumçayı on defa ciddi taşkın yapmış, ahalinin can ve mal kaybına sebep olmuştur (Satılmış, 2012: 271-282). Gediz Nehri çevresindeki köylerde gerçekleştirilen arazi araştırmaları sırasında taşkınların halkın hafızasında hala yaşadığ görülmüştür. Gediz ve ona bağlı kolların çevresinde bulunan XVI. yüzyıl yerleşmelerinden 24'ünün ortadan kalktığı görülmektedir. Bu köylerin halkı toptan göç ederek başka yerleşim birimlerine dağıldığ anlaşılmaktadır.

Konya çevresinde güçlü bir akarsu yoktur ancak burada da yoğun sağanak yağışlarda, küçük derelerin taşkına ve ani olarak yüzeysel akışa geçen suların sellere neden olduğu görülmektedir. Öreğin, 1502-1505 yılları arasında Osmanlı ülkesinde meydana gelen aşırı yağışlar nedeniyle birçok nehir taşkın 
yapmış, göl seviyeleri yükselerek su basmalarına neden olmuş ve Solakzade'nin ifadesiyle "Konya sahrası derya misali" (H.1297, M.1879/1880 yzlinda) sular altında kalmıştır (Demirtaş, 2004: 40). Konya sahrası olarak ifade edilen yer hiç şüphesiz Konya Ovasına karşılık gelen alandır. Geçmişte ve hatta yakın döneme değin bu mekânlar suğlaların oluştuğu sahalardır. Yağışların oldukça fazla olduğu söz konusu tarihte çukur alanlarının birçoğunda sular toplanarak adeta bir göl haline gelmiş ve böylesi bir anlatıma konu olmuştur (Yiğit, 2017: 345-346).

Tibbi imkânlarının oldukça yetersiz ve geride olduğu geçmiş dönemlerde insanların karşı karşıya kaldığ sorunlardan birisini de salgın hastalıklar oluşturmaktadır. Araştırmaya konu edinilen zaman dilimi içerisinde insanların en önemli problemleri arasında veba (taun) ve sitma gelmektedir. Bu türden sağlık problemleriyle karşı karşıya kalan insanlar toplu ölümlerin başlaması ile birlikte yaşadıkları mahalden ayrılarak göç kervanına katılıyorlardı. Bir kısım köyler mevcut yerinden kalkarak yeni bir mekânda varlığını devam ettiriyor, bir kısmı ise başka köylerle birleşmek suretiyle hayatlarına devam ediyorlard1. Her iki durumda da bir yer değişikliği söz konusu olup ilkinde köy tüzel kişiliği aynı adla devam ederken ikincisinde köy tüzel kişiliği ortadan kalkarak gittikleri yerleşmenin adıyla mevcudiyetlerini sürdürüyorlardı.

Manisa'da gerçekleştirilen arazi araştırmaları sırasında ortaya çıkan salgın hastalıklar başta olmak üzere bir kısım köylerin toptan göç ettikleri bazılarının ise güvenli ve merkezî konuma sahip yerleşme merkezlerinde toplulaştığ1 (Gümüşçü vd., 2016: 428) görülmektedir. Manisa’da 9 köyde salgin hastalıkların hatıralarda yaşadığ 1 (Harita 2) ve bu durumun köylerin zaman zaman yer değiştirmesine ve belirli noktalarda birleşmesine neden olduğu görülmüştür. ${ }^{5}$

Manisa çevresindeki salgın hastalıklara ilişkin bakınız. İlker Yiğit ve Osman Gümüşçü, 2016. "Manisa ve Çevresinde Salgın Hastalıkların İskana Etkisi (XVI-XX. yy.)", TÜCAUM Uluslararası Coğrafya Sempozyumu 13-14 Ekim 2016, Ankara, s. 379-391. 


\section{Harita 2. Manisa Çeoresinde Salgın Hastalık Olan Bazı Yerleşmeler}

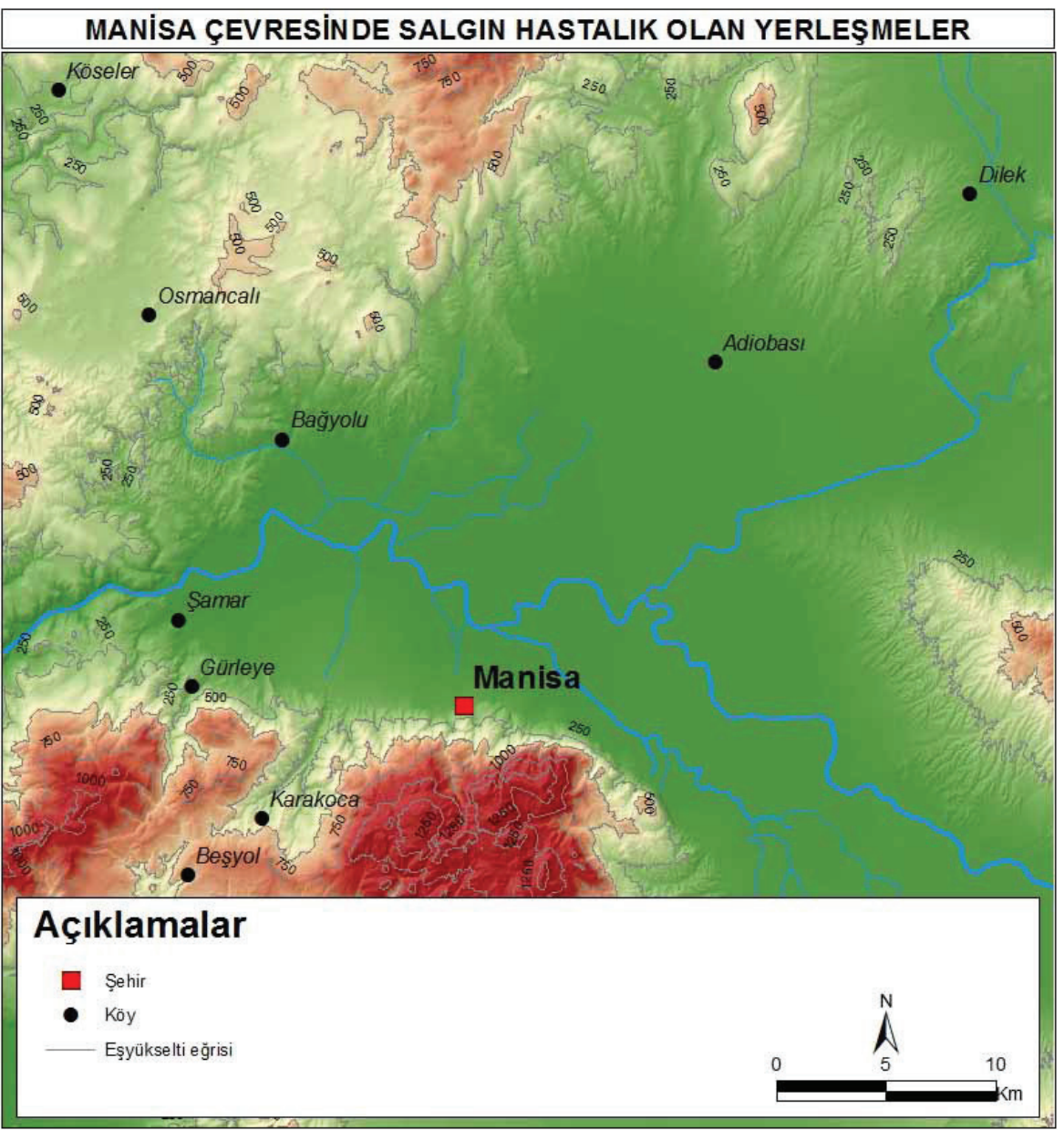

Manisa Adilobası köyünde, veba hastalığı veya beyin humması nedeniyle Toyyusufluk ve Simad köyleri terk edilerek Adilobası köyünde toplanmıştır (Erol Yener'den alınan sözlü bilgi). Yunddağ1 Köseler köyünden alınan bilgiye göre, bugün Gözeler adı verilen ve ev harabelerinin bulunduğu yerleşim yeri (XVI. yüzyıl Gürzeler) veba sebebiyle terk edilmiştir. Ayrıca Ovacık ismi verilen mevkide de salgın hastalık meydana geldiği için Köseler köyüne ahali gelerek yerleşmiştir. Bunlar yerel halkın hafızasında yaşayan ve bizim ulaşabildiğimiz sözlü bilgilerdir. Bir de süreç içerisinde unutulan ya da bir şekilde ulaşılamayan hususlar göz önüne alındığında durumun ciddiyeti ve göçe olan etkileri daha iyi değerlendirilebilecektir. 


\section{2-Eşkıyalık faaliyetleri}

Osmanlı ülkesinde XVI. yüzyılın ikinci yarısından itibaren şehzadeler arası mücadelede kullanılan tüfekli birlikler Anadolu'ya yayılarak ellerindeki ateşli silahlar ile sosyal düzeni etkilemeye başlamışlardır. 1559 yılında neredeyse tüm Anadolu'da yaygın bir hal alan suhte isyanları, medrese kapılarında toplanan talebeler içinde bulundukları sosyal ve ekonomik buhranın teşvik ve tahriki ile kanun dışı yollara saparak halktan haraç almaya ve çeşitli ahlaksızlıklara konu olmuşlardır. XVI. yüzyılın sonlarında ve XVII. yüzyılın başlarında sarıca-sekban birlikleri başıboş leventler işsizlik, ekonomik sıkıntılar vb. gerekçelerle ancak temelde karnını kolay ve gayri kanuni yollardan doyurmay1 tercih ederek devletten bir makam ve mansip elde etmeye yada kaybettiği eski itibarını kazanmak isteyen Celâli şeflerinin arkasında saf tutmuşlardır. $\mathrm{Bu}$ dönemde, pek çok arşiv vesikasında geçtiği ve araştırmalara yansıdığ1 üzere, özellikle kırsal alanda yaşayan insanlar gördükleri zulümler karşısında kitlesel göç hareketlerine katılmışlardır.

Manisa şehrinin tekalif türü vergilerden muaf tutulması (Emecen, 2003: 580) buraya yapılan göçleri hızlandırıcı bir faktör olmuştur. Kırsal alanda eşkıya, ehli örf baskısı, doğal koşulların ortaya çıkardığı itici faktörlerin yanında şehrin cazibesi de insanları buraya göç etmeye teşvik etmiş olmalıdır. Eylül 1635 'te gönderilen bir fermanda özellikle Celâli isyanlarından kaçıp insanların şehirlere sığınması nedeniyle zeamet ve timar arazilerinin boş kaldığı ve üretimin zarar gördüğü belirtilmiştir. Bu nedenle 40 yıla kadar göç etmiş olanların kadim yerlerine döndürülmesi hususunda daha önceden emir çıkartılmıştır. Ancak bunun Manisada uygulanmadığına binaen Manisa ve çevre kazalardaki kadılardan ahalinin yerli yerine gönderilmesi tekrar istenmiştir (Uluçay, 1944: 158-159). Manisa çevresinde Celâli isyanlarının kırsaldan ciddi göçlere neden olduğu bunların bir kısmının şehirlere bir kısmının ise şehre yakın köylere gelerek yurt tuttuğu arşiv vesikalarına yansımıştır. Manisa Şer'iye Sicili’ne yansıdığı kadarıyla Kesdoğan, Çiftlik, Akain, Sarıyer, Sarukaya, Koyun Abdalı, Selçukhan ve Tuzhisarı karyelerinde meskûn olan zimmi reaya Celâli isyanları nedeniyle oturdukları köylerden kalkarak Manisa şehrindeki Yenice mahallesine ve şehrin mücavir alanındaki köylere yerleşmiştir (MŞS 49, 161/3).

Osmanlı Anadolu'sunda ve araştırma alanlarında kırdan şehire göç yaşandığ 1 gibi kırdan kıra göç olaylarının gerçekleştiği de görülmektedir. Söz konusu göçler nedeniyle merkezî konuma sahip güvenli, kalabalık köyler birer çekim merkezî olarak etrafındaki yerleşmeler için bir toplanma sahası haline gelmiştir. Merkezî ve korunaklı köylere gelen insanlar ilgili sahadaki (göç 
ettikleri eski köy arazilerindeki) tarım alanlarını işlemeye devam ederek üretimin devamlılı̆̆ını sağlarken göç ettikleri köylerde avarız türü vergilere (Sahillioğlu, 1991: 108; Ünal, 1997: 10) ortak olmaları bu göçü kolaylaştıran ve büyük problemlerin çıkmasını engelleyen bir husus olmuştur. Yaşanan bu süreçte kırsal alanda bazı köyler terk edilirken gerçekleşen göçler, göç çeken iskân merkezleri için adeta can suyu olarak yerleşmedeki devamlılığı sağlayan önemli bir etken olmuştur.

Yakın köyler arasındaki göçler neticesinde tarımsal faaliyetlerin devam etmesinin yanında kırsal alandan şehre göç edenler de haftanın belirli günleri giderek köydeki tarlalarını işlemeye devam etmişlerdir (Gümüşçü vd., 2016: 479). 14 Kasım 1718 tarihinde Konya mahkemesinde görülen bir davadaki bilgi bu duruma örnek teşkil etmektedir. Bayburt kazasına tabi Göçi karyesi ahalileri mahkemede aslen Karakaya karyesinden olup Konya'da Polatlar Mahallesi'nde sakin olan Üveys, İvaz ve Mehmed'in tekrar kadim karyelerine dönmeleri için emir olmasına rağmen dönmemişlerdir diyerek ilgili kişilerin Göçi'ye iskân edilmelerini istemişlerdir. Üveys ise savunmasında 40 sene önce Karakaya köyü ahalisinin dağıldığını ve kendilerinin şehre gelip yerleştiklerini, yalnız yaz aylarında Karakaya arazisini ziraat etmek için birkaç gün gittiklerini bildirmiştir. Dinlenen şahitler de 30 seneden beri Üveys, İvaz ve Mehmed'in Polatlar mahallesinde sâkin olduklarını ifade etmeleriyle Göçi ahalisi davayı kaybetmiştir (KŞS. 48, 159/1).

Kasım 1610 tarihli bir kayda göre şehre geldikten sonra mal mülk sahibi olan kişiler sipahilerine vergilerini vermelerine rağmen hariç kimselerin bu insanları köylerine döndürmek için "elimizde emir vardır" diyerek paralarını almışlardır. Merkezî hükümete iletilen bu durum üzerine köylülerin "öşr-i salariye ve hukuk-i şer'iyelerini” sipahilerine verdikleri için müdahale edilmemesi gerektiği ve Manisa şehri ahalisinin avarızdan muaf olduğu hatırlatılarak halkın rencide edilmemesi gerektiği kadıya bildirilmiştir (MŞS 41, 152/1). Şu halde Manisa çevresinin avarızdan muaf olması (Emecen, 2003: 580) kırsalda yaşanan olumsuzluklar ve özellikle vergi baskısından kurtulmak isteyen insanlar için bir sı̆̆ınak mahalli ve cazibe merkezîdir. Manisa şehrinin bu cazibesinden öte daha dikkat çeken husus ise göç edenlerin sipahilerine olan vergilerini ödemeye devam etmeleri ve güvensizlik ortamında kırsal alandan göçün zımnen de olsa meşru görülmesidir.

Normal şartlar altında ahalinin çiftini çubuğunu terk etmesi yasak olmasına rağmen sipahiye vermesi gereken vergileri ödemeye devam etmesi sipahi-köylü çatışmasının önüne geçmiştir. Zira çift-bozan hale gelen reayanın peşine düşerek geri döndürme yetkisi olan timarlı sipahinin böyle bir yola 
tevessül etmemesi gerek köyden-köye ve gerekse köyden-şehre olan göçlerde böyle bir mekânizmanın işlediğine dair önemli bir ipucudur. Mahkeme ve arşiv kayıtlarına yansımayan durumların daha fazla olduğu/olabileceği hatıra getirildiğinde tarihi süreçte kaybolup giden birçok köylü özellikle yakın köylerde meydana gelen toplulaşma neticesinde tarlasını işlemeyi ve vergisini ödemeyi sürdürdüğü makul görünmektedir. Bu husus da kırdan şehre olan göçlerden belki daha fazla miktarda köyden-köye göçün mevcudiyetini düşündürmektedir.

Bilindiği üzere yollar ve ana ulaşım güzergâhları yerleşmelerin kurulması ve dahi gelişmesinde önemli faktörler arasında yer alan hususlardandır. Ancak Celâli ve eşkıyalık faaliyetlerinin kol gezdiği dönemlerde yola yakın olmak, özellikle de yol üzerinde bulunmak iskânı olumsuz etkileyen ve göçe neden olan bir faktör olarak karşımıza çıkmaktadır. Böylesi asayişsizliğin yaygınlaştığı zaman dilimlerinde, yol cazibesini yitirerek adeta insanları ilgili sahadan ayrılmaya zorlayan itici bir faktör olarak karşımıza çıkmaktadır. Bu durum araştırma alanımız olan Konya'da gerçekleştirilen saha araştırmaları vasıtasyyla gözlemlenmiştir. Konya'dan Isparta ve Akşehir istikametine devam eden kervan yolu Altunapa vadisinden geçmektedir. Söz konusu vadiyi takip eden yol üzerinde üç kervansarayın (Altunapa, Kavak ve Elikesik hanları) yer alması bu ulaşım arterinin önem ve işlevselliğini göstermesi açısından dikkate değer bir durumdur. Güzergâhta yer alan köyler büyük kargaşa ve kaos dönemlerinde özellikle Celâli ve eşkıyalık faaliyetlerinin zirveye ulaştığı zaman dilimlerinde ilk etkilenen ve göçün yaşandığı mekânlar olarak değerlendirilebilir. Zira bu yol üzerinde bulunan bazı köylerin ahalisi toptan göç ederek yerleşmeler ortadan kalkmıştır. Yol üstündeki köy halkının yoldan uzak, güvenli gördükleri bir diğer köye toptan göç etmişler ve söz konusu köyler (XVI. yüzyıl Çeltek, Dilkemi, Devletşah ve İne Devle karyeleri gibi) böylece kaybolarak silinip gitmiştir. Bazı köyler de 2-3 kilometre vadi içlerine taşınma suretiyle yeni bir kuruluş mekânı seçerek hayatiyetini devam ettirebilmiştir. 3-5 kilometre mesafeyi bulabilen bu uzaklık insanların eski köylerinin arazisini işlemesine mani olmamış kendileri taşındıkları yeni köyde otururlarken çift ve harman zamanı eski köy yerine giderek tarımsal faaliyetlerini devam ettirmişlerdir (Harita 3). 


\section{Harita 3. Konya Çevresinde Kervan Yolu ve Kaybolan Yerleşmeler}

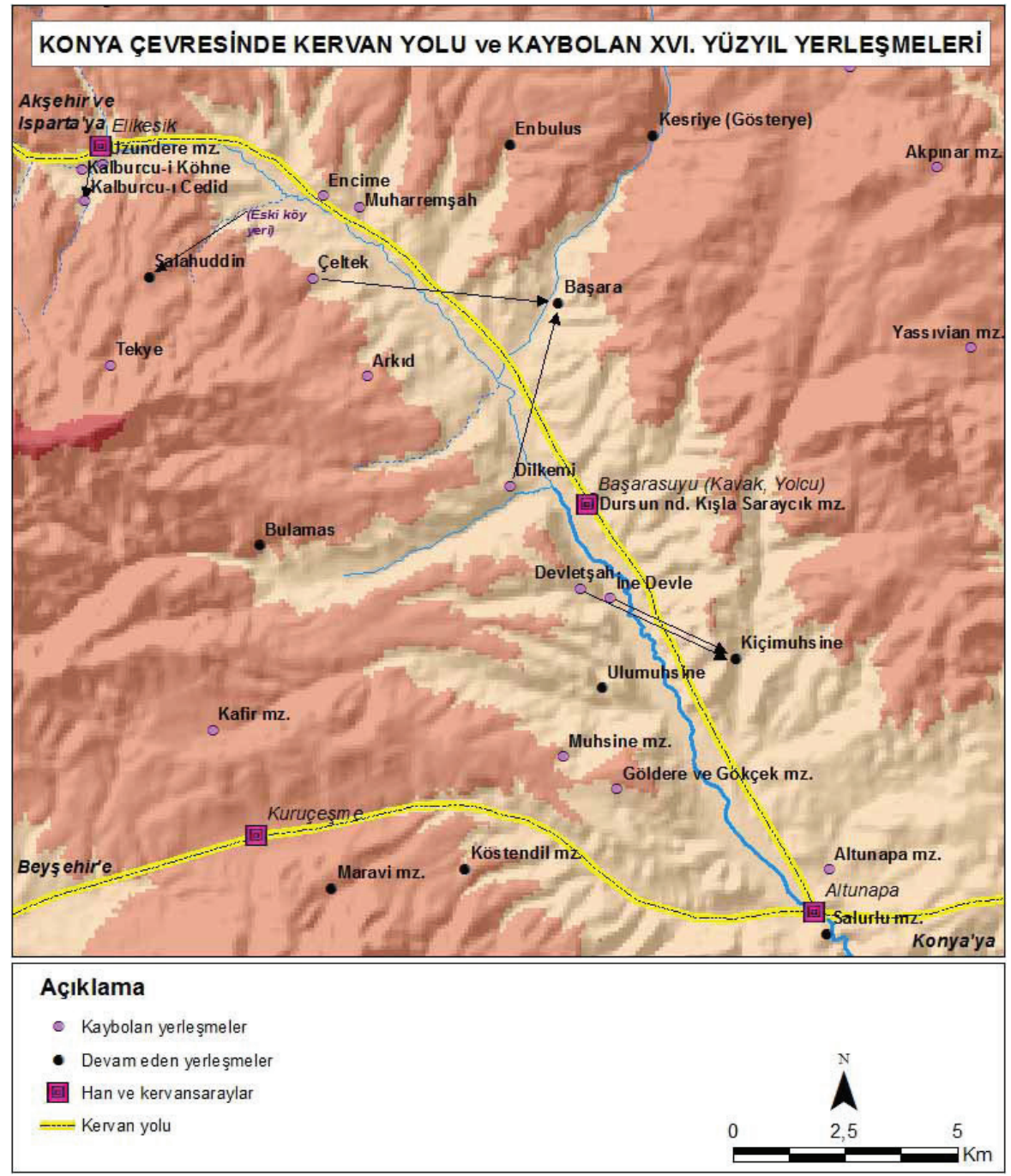

Eşkıyalık faaliyetlerinin arttığ 1 dönemlerde şehirler, görece daha korunakl1, palangaya sahip ve kalabalık köyler kırsal nüfusun çekim merkezleri haline gelmiştir. Yakın köylere göçen halk arazisini işlemiş, üretime devam etmiştir. Ancak zaman zaman dağılan köylerin sahibi arz tarafından tekrar kadimi yerlerine toplanıldığı da kayıtlara yansımıştır. Konya Kalesi muhafızlarına tahsis edilen Yarımca karyesi ahalisinin dağılmasının ardından köylülerin tekrar toplanması ve kadim yerlerinde iskânları için emir çıkartılmıştır (KŞS 26, 71/2). Zuamadan İshak Ağganın vekili ve subaşısı olan Mürsel Bey, Söğüt 
karyesi sakini Hacı Mustafa'dan davacı olmuştur. İshak Ağa'nın zeamet karyelerinden Yenice köyünde meskûn iken Hacı Mustafa'nın Söğüt karyesine göçtüğünü ancak iki seneye değin vergisini Yenice karyesinde vermekte iken iki senedir üzerine düşen vergiyi ödemediği belirtilmiştir. Yenice karyesinden şahitlerin dinlenmesi neticesinde Hacı Mustafa'nın iki seneye değin vergisini burada verdiği bilgisine ulaşılmıştır. Mahkemede Hacı Mustafa'nın iki senelik vergilerini vermesi ve bundan sonra karşı çıkmaması üzerine konu hükme bağlanmıştır (25 Mayıs 1686) (KŞS 31, 48/3).

I. Dünya Savaşı ve Milli Mücadele döneminde kırsal alanda eşkıyalar türemeye ve kol gezmeye devam etmiştir. Ülkenin içinde bulunduğu durumu firsat bilen bazı kişiler dağlık alanlardaki köylerde yem, yemek, para ve erzak temini noktasında çevre köyleri kullanmak istemişlerdir. Eşkıya çeteleleri, yardım etmeyen ve karşı çıkan köylere ise baskın düzenleyerek insanların buraları terk etmelerine ve iskân sahalarının harabe hale gelmesine sebebiyet vermişlerdir. Bu minvalde bir örnek Manisa çevresinde, arazi araştırması vasıtasıyla tespit edilmiştir. Turpçular isimli köy daha önceden yola yakın düz bir sahada iken insanlar eşkıya baskısı nedeniyle tepe bir noktaya çıkarak yerleşmelerini buraya kurmuştur. Ancak "Cihan Harbi zamanında" eşkıyaya karşı ellerindeki silahlar ile mücadele etseler de bir yere kadar dayanabilmişler ve en sonunda köyü terk etmek zorunda kalmışlardır (Ramazan Kaya, Hasan Keskin ve Kadir Şenpak'tan alınan sözlü bilgi) (Foto 1).

\section{Foto 1. I. Dünya Savaş̧ı Sırasında Eşkıya Çetelelerinden Dağılan Turp̧̧ular Köyü Harabesi}

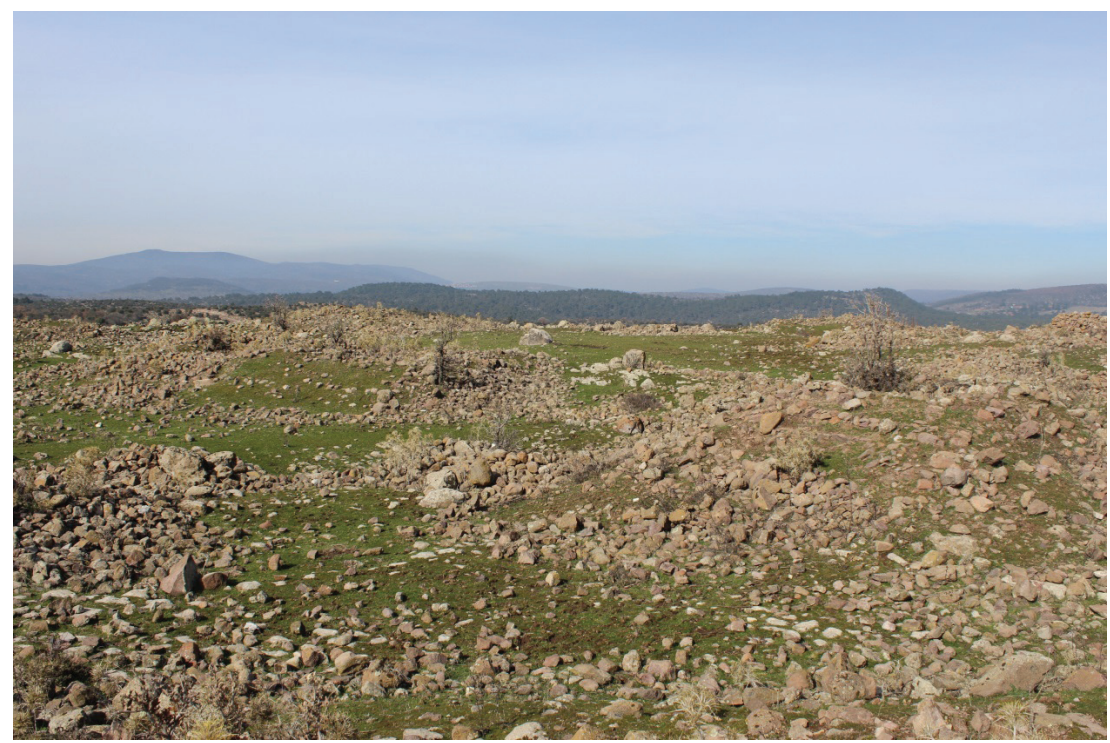




\section{3-Vergi Baskısı}

Osmanlı Devleti'nde temel vergi ve toprak sistemi çifthane sistemi tabiriyle kavramsallaştırılmıştır. Çifthane sistemi ise arazi, vergi ve hane sayımları sayesinde tespit edilmekteydi. Burada vergi haneden alınırdı, ayrıca hane olağanüstü durumlarda toplanan teklif türü (avarı) vergiler için de mali bir birim niteliğini taşıyordu. Osmanlı Devleti örfi vergi ve yükümlülüklerinin çoğunu çift resmi ile ilişkili hane esasına göre rüsum, tekalif-i örfiyye ve avarız-1 divaniyye sistemi altında sürdürüyordu (Gümüşçü vd., 2016: 213; Kenanoğlu, 2013: 56).

Osmanlı döneminde alınan şer’i ve örfi vergileri ödemeye devam eden halkın avarız gibi ilk başlarda olağanüstü hallerde toplanan verginin daimi bir hal alması, yeni tip vergi usullerinin ortaya çıkması, kırsal kesimde yaşayan halkı etkileyen önemli durumlar arasında yer almaktadır. Bu vergi kalemlerinin altında zorlanmasının dışında devlet görevlilerinin ve vergi toplayıcılarının kanun dışı fazla miktarda para toplamaları, devre çıkıp yem ve yemeklik talep etmeleri, köylünün belini büken durumların başında gelmektedir. Bir de eşkıyalık faaliyetlerine maruz kalan köylülerin olan biten onca şey karşısında katlanacak durumunun ve esnekliğinin kalmaması ayrıca hatırda tutulmalıdır. Olağan ve olağanlaşan vergilerini bir şekilde ödeyen ya da ödemeye gayret eden ahalinin yerini yurdunu terk etmesine sebebiyet veren durumun belgelere yansıdığı kadarıyla ağır vergi ve mükellefiyetlerin yanında kanun ve defter dişı haksız talepler olduğu görülür.

Dönemin kaynaklarında devlet görevlilerinin türlü bahaneler öne sürülerek halktan cebren vergi topladıklarına sıkça rastlanmaktadır. Konya Bab-1 Aksaray mahallesinde yaşayan Ali ve İbrahim isimli kişiler avarız ve tekaliflerini yerine getirdikleri halde Sahra nahiyesi Gündür (?) isimli köyün sipahisi ve Konya kalesi mustahfizlarından olan iki kişi, Ali ve İbrahime, "sizin dedeniz benim köyümde sakin olmuş raiyyetimdir, sizler de benim raiyyetimin oğullarısınız" diyerek raiyyet rüsumu ve çift-bozan vergisi talep etmiştir (Temmuz 1672) (KŞS 16,174/3). Sipahiler köyde arazi emlakı olmamasına rağmen göç eden kişiden hala raiyyet rüsumu ve çift-bozan vergisi istemişlerdir. Konya kazası Sudiremi nahiyesine bağlı Kiçimuhsine isimli köyün sipahisi olan Bektaş Ağa'nın vekili Seyyid Mehmed Ali isimli kişi, Burçaklu mahallesinde meskûn olan Molla Aliden köyün raiyyeti olduğu halde raiyyet rüsumunu ve çift-bozan vergisini vermediği gerekçesiyle davacı olmuştur. Yapılan inceleme neticesinde köyden geleli 40 sene olduğu ve şehirde bulunduğu mahallede üzerine düşen mükellefiyetleri yerine getirdiği anlaşılarak dava Molla Ali lehine sonuçlanmıştır (31 Ağustos 1785) (KŞS 64, 84/2). 
Manisa, Menemen ve Yengi kadılarının arzuhaline verilen cevap da taşradaki haksız uygulamalar hakkında birtakım fikirler vermektedir. Bölgede sipahi oğlanı, cebeci, topçu, beylerbeyi ve sancakbeylerinin voyvodaları, subaşılar ve bazı eşkıyalar vs. ortaya çıkarak insanların malına ve canına zarar verdiği, yem ve yemeklerini aldıkları, aydan aya köylerden akçe toplayarak zulmettikleri bildirilmiştir (Haziran 1598) (Uluçay, 1944: 178-179). Fazla vergi noktasında Haziran 1606'da Saruhan sancağındaki kadılara gönderilen hüküm bölgedeki asayişsizlik ve halk üzerindeki baskıya ilişkin durumu net bir şekilde ortaya koymaktadır. Sancakbeyi kethüdaları 200-300 atlı, ümena, ummal, mültezim, nuzzar 100-200 atlı ile gezerek halktan bedava yem ve yemeklik almaktan da öte halkın canına ve ırzına tasallut etmişlerdir. Sancakbeyi kethüdaları köy köy dolaşarak sebepsiz ve kanunsuz bir şekilde 5-10'ar akçelerini almak suretiyle senede 200.000 akçelerini gasp etmişlerdir. Subaş1larda konak, göçek adı altında 600-700 akçe toplamıştır. Ummal, ümena, mültezim ve nuzzarlar önceden 24'er akçe alınagelen yerlerden 150-200'er akçe; 33 akçe alınması gereken yerden 200'den fazla akçe; resmi ağnam koyun başına 1 akçe iken 10 'ar ve daha fazla akçe almışlardır. Ayrıca 100-200'er atlı ile köylerde gezerek zulmettiklerinden ellerinde hiçbir nesnesi kalmayan insanlar da "cümlemiz celay-1 vatan ve terk-i mesken edüb her birimiz bizzarure bir diyara perakende ve perişan olmamız mukadderdir” diyerek durumlarını İstanbul'a bildirmişlerdir (Uluçay, 1944: 117).

Bölgedeki devlet görevlileri ve bunların adamları kırsalda kalabalık maiyyetleri ile teftişe çıkıyorlardı. Meslea, 28 Mart 1655’te Manisa Çobanisa köyüne 600 atlı ile gelen Zeynel Abidin Paşa, halktan "konakçı akçesi" adı altında 15.514 akçeyi bulan mallarını (yem, yemeklik, içecek vb.) gasp etmiştir. Ayrıca Sarıca ve Toyyusuflu köylerinde 2 Nisan 1655 tarihinde 500 adamı ile "konakçı" namıyla konarak 30 kuruşlarını, 70 kile şair (arpa), 10 kuzu, 200 adet tavuk vs. almak suretiyle halka zulüm etmiştir (Uluçay, 1944: 341-342).

Avarız vergilerinin özellikle XVII. yüzy1ldan itibaren sürekli bir hal almasının (Özel, 2000: 37-38) halk üzerinde ciddi etkileri olmuştur. Çeşitli olumsuzluklarının yanında bir de avarız vergisinin daimi bir hale gelmesi köylü ahaliyi göç etmeye zorlayan faktörler arasındaki yerini almıştır. Yapılan çeşitli araştırmalar ile ortaya konulduğu üzere avarız defterlerinde geçen avarız hane teriminin gerçek hane olmayıp itibari bir birim olduğu tespit edilmiştir. Bu defterlerde geçen avarız hane, ilgili yerleşim biriminde yaşayan nefer sayısı olmayıp onların mali gücünün dikkate alınması neticesinde ortaya çıkan bir rakamdır (Uluçay, 1944: 13-14; Sahillioğlu, 1991: 108-109; Özdemir, 1993: 1581-1613; Tızlak, 2010: 114-123; Küpeli, 2011: 121-122; Gümüşçü vd., 2016: 355-358). Söz konusu bu verginin nefer başına değil de ilgili yerleşme- 
nin mali gücüne göre itibari bir avarız hane tespit edilerek alınması kırsalda göçün yaşanmasının nedenlerindendir. Zira avarız vergisinin baskısı altında ezilen halk büyük bir köye göç ederek oradaki avarız vergisine ortak oluyordu. Yeni gelen göçmenlerin ilgili köydeki vergi yükünün altına girmesi iki tarafın da işine geldiği ve böylece hiçbir sorun yaşanmıyor olduğu söylenebilir.

Araştırma alanlarımız olan Manisa ve Konya çevresinde gerçekleşen göç olayları neticesinde geride kalanların avarız vergisini ödemekte zorlandıkları dönem belgelerine yansımıştır. 1698 tarihinde Manisa kazası ahalileri mahalle ve köylerde halkın eşkıya sebebiyle dağıldığı gerekçesiyle avarız vergilerinin düşürülmesini talep etmişlerdir. Manisa şehri, Belen, Turgud, Palamud, Yunddağı ve Emlak nahiyelerindeki avarız hane sayısı 1306,5'ten 1000'e düşürülmüştür (Uluçay, 1944: 468-469). 27 Mart 1699 tarihinde Konya kazasındaki reayanın bir kısmı perakende ve perişan olduğu için geriye kalanların 366 avarız hanesine ödemeye güçleri olmadığı gerekçesiyle avarız hanelerinde indirim talep etmişler ve merkez tarafindan kazanın 30 avarız hanesi düşürülmüştür (KŞS 5, 19/2). Avarız baskısının etkisiyle bir merkezden göç edenler vergi yükünden kurtulurken geride kalanlar için mali yükün tahammül edilemez bir hal aldığı anlaşılmaktadır. 1670 tarihli bir vesikaya yansıdığı üzere, Manisa, İzmir, Kula, Demirci ve Uşak kazaları kadılarına gönderilen bir hükümde Güre kazası ahalisinin dağıldığı geride kalanların ise onların avarız hanelerini çekmeye güçlerinin olmadığını bildirdikleri için dağılanların tekrar kadim yerlerine gönderilmeleri ve gerekenlerin yapılması emredilmiştir (Uluçay, 1944: 391).

9 Ağustos 1664 tarihinde bu kez Bayburt kazasından insanlar gelerek Kise Kilise ve Kara Ömer köylerinin Bayburt kazasına tabi olmasına rağmen avarız vergilerini İnsuyu kazası ile birlikte verdikleri gerekçesi ile ilgili köylüler hakkında davacı olmuşlardır. Ancak defter-i hakani üzerinde yapılan incelemeler neticesinde avarız vergisinde İnsuyu kazası kaydedildiği ancak diğer vergileri bağlı olduğu Bayburt kazası ile birlikte vermesi gerektiği görülerek itiraz reddedilmiştir (KŞS 12, 205/3).

Konyaya bağlı Sudiremi nahiyesi Penbeci köyü ahalisi mahkemeye (17 Mayıs 1664) gelerek Satılmış ve İbrahim isimli kişiler hakkında köylerine düşen tekalifi ödemesini istemişlerdir. Satılmı̧ ve İbrahim ise köyün daha önce toptan terk edildiğini ve kendisinin de bu zamanda şehre gelip yerleştiğini belirttikten sonra mahallede avarız vergisini ödediğini belirtmiştir. Mahkeme Satılmı̧̧ ve İbrahim lehine sonuçlanmıştır (KŞS 12, 156/2).

Yukarıda verilen örneklerin yanında avarız türü vergilerin baskısından köylü ahalinin bir hane daha yükümlülük alacak kişi arayışına girmesi duru- 
mun ciddiyetini göstermesi bakımından dikkate değer bir husustur. 9 Ekim 1674'te İnsuyu kazasına bağlı Ağcakuyu sakinleri mahkemede, Konya şehrinde Sinanperakende Mahallesi'nde oturan Ali hakkında yaz aylarında gelip bizim köyümüzde sakin olup kışın şehre gitmektedir ancak biz daima bizim köyümüzde oturmasını isteriz demişlerdir. Bu durum üzerine Ali, atalarının Tutub isimli köyde sakin iken tüm ahalisinin dağıldığını, kendisinin de ilgili mahalleye geleli 50 seneyi geçtiğini ve yalnızca birkaç senedir yaz aylarında Ağcakuyu köyüne gittiğini ifade ederek davayı kazanmıştır (KŞS 20,7/1). Bu örnek bir kişi dahi olsa kendi köylerinin nüfusunu ve böylece vergi mükellefi kişi sayısını artırma amacını göstermektedir.

Konya çevresinde köyden-köye gerçekleşen göçlerle ilgili olarak arşiv vesikalarından örnek vermek de mümkündür. Konya Kalesi muhafızlarından ve Orduözü karyesi timarı olan Süleyman hakkında Harem ağalarından Abdullah Ağa'ya vekaleten Mehmet Ağa davacı olmuştur (20 Temmuz 1681). Mehmet Ağa, Orduözü karyesine mülhak Mürde karyesindeki Nurullah'ın büyük dedesi Yunus isimli kişi müvekkili olduğum Abdullah Ağa’nın zeamet karyelerinden olan Çomaklar karyesinde kayıtlı iken Mürde karyesine göç etmiş, vergileri burada Süleyman tarafından alınmış ve kendisinin bu raiyyetlerden vergi alamamış olduğunu iddia etmiştir. Yapılan inceleme ve şahitlerin dinlenmesi sonucunda yüz senedir Mürde köyü raiyyeti oldukları anlaşlınca davayı mustahfız Süleyman kazanmıştır (KŞS 25, 255/1). Bu örnek durum kırsaldaki göçün yönünü net bir şekilde ortaya koyması bakımından önem arz etmektedir.

Verilen bu örneklerden de açıkça görüldüğü üzere halk, haksız ve fazla vergi taleplerinden dolayı çeşitli sıkıntılar yaşamıştır. Halk, zaman zaman kazalarındaki avarız yükünü çekecek kişilerin kayıtlarını kendi kaza ve köylerine taşıyarak bu yükü hafifletme girişimleri olmuştur. Yaşanan ekonomik sıkıntılar karşısında ahalinin bazısı yerini yurdunu terk ederek kırsal alanda köylere ve şehirlere göç etmiştir. Geride kalanlar ise vergiyi ödemeleri mümkün olmad1ğ 1 için toptan göç etmişlerdir.

\section{Kırsal Alanda Toplu Göçler ve Köyler}

Yerleşmelerin kuruluşu, gelişimi, devamlılığı ve ortadan kalkması nüfus hareketleriyle yakından ilgilidir. Nitekim bu husus İ. Tekeli tarafından şu cümlelerle ifade edilmiştir: "Göç, yerleşme sisteminin değişen koşullara uyumunu sağlayan bir toplumsal süreçtir" (Tekeli, 2011: 163). Gerçekten de göç faaliyetinin yaşandığ 1 yerleşmelerin çeşitli uyum süreçleri geçmiş dönemlerde de gözlemlenebilmektedir. Nitekim araştırma alanlarında çalışılan dönem 
içerisinde köylerin toptan göç ettiği görülmüştür. Bu durum bazen iki iskân merkezînin farklı bir yerde birleşerek tek bir isim altında yaşaması şeklinde olabildiği gibi bazen de merkezî ve güvenli bir yerleşmenin çevresindeki köylerin nüfusunu tamamen kendi bünyesine çekerek büyümesiyle de sonuçlanabilmektedir. Her iki halde de bir göç meselesi vardır ve bu durum bireyin ve ailenin hareketliliğinden ziyade köy halkının topyekûn göçü olarak karş1mıza çıkmaktadır.

Konya çevresinde gerçekleştirilen arazi araştırmaları sırasında diğerlerine nazaran güvenli ve merkezî olan köylere yönelik gerçekleşen toplu göç hareketleri tespit edilmiştir. Başka bir ifade ile bu durum kırsalda köylerin toplulaşması (Gümüşçü vd., 2016: 428) meselesidir. Bu türden bir durumun doğal, sosyal ve ekonomik çok farklı cepheleri vardır. Nitekim bu şekilde gerçekleşen göçlerin itici ve çekici sebeplerinin tamamından etkilenmesi muhtemel bir durum olarak değerlendirilebilir.

Konya çevresinde XVI. yüzyılda mevcut olan Kavak köyü, kırsalda meydana gelen toplu göçlerin hala yerel halkın hafızasında yaşadığı oldukça önemli bir örneği teşkil etmektedir. Bu köyde gerçekleştirilen görüşme sırasında ilgili kişi "bu köy yedi viran üzerinde oturuyor", "yedi köy dağ1lip göç etmiş ve burada toplanmış" dedikten sonra viran yerleşmeleri sayıyor ve rakamın 10' a çıktığ1 görülüyor (Mustafa Sade'den alınan sözlü bilgi) (Tablo 1):

Tablo 1. Kavak Köyünde Toplanan Yerleşmeler ve Son Kayıt Taribleri

\begin{tabular}{|l|c|c|c|}
\hline \multicolumn{1}{|c|}{ Köy Adı } & Son Kayıt Tarihi & Köy Adı & Son Kayıt Tarihi \\
\hline 1-Kuduref & 1530 & 6-Virancık & 1750 \\
\hline 2-Dinorna & 1667 & 7- Gömse & 1831 \\
\hline 3-Kuyucak & 1585 & 8-Çeşme & Yeni kurulan köy \\
\hline 4-Dinek & 1697 & 9- Çiviköy & Yeni kurulan köy \\
\hline 5-Çatköy & 1704 & 10- Havzan & Yeni kurulan köy \\
\hline
\end{tabular}

Kaynak: BOA.TD 387; TK.KA 104; KŞS, 9, 20, 23; Konya Nüfus Defteri No: 3447; Konya Kazası Hurufat Defteri No: 1107.

Kavak köyünde gerçekleştirilen görüşme neticesinde ifade edilen 10 virandan 7'sinin XVI. yüzy1lda Konya çevresinde mevcut olan köyler olduğu tespit edilmiştir. Şu halde Kavak köyü çevresindeki kırsal iskân merkezleri süreç 
içerisinde farklı tarihlerde mevcut yerleşmelerinden kalkıp buraya gelerek toplanmışlardır (Şekil 1). Kavak köyünde toplanan köylüler süreç içerisinde eski köylerindeki tarlaları işlemeye devam etmiş olmalıdırlar. Terk edilen köylerin arazileri faal olarak üretime konu olsalar da iskân çekirdekleri zamanla harap olarak silinip gitmiştir.

\section{Şekil 1. Kavak Köyü Toplulaşma Şeması}

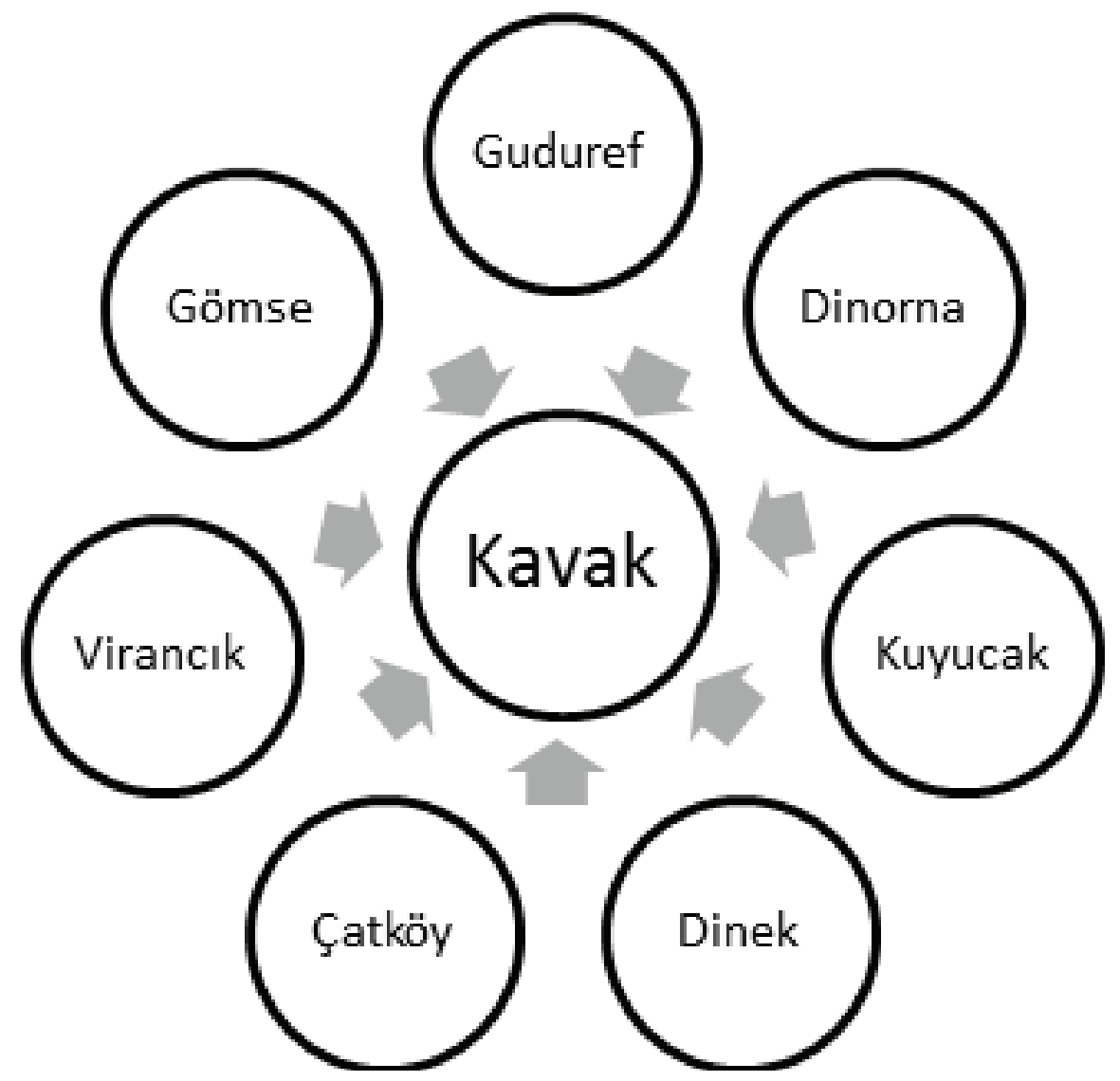

Kavak köyünde toplanan kişilerin arazilerini işlediğine dair birtakım ipuçlarına arşiv vesikalarından da ulaşmak mümkündür. Konya Şer'iye Sicili’ne 1667/1668 tarihinde yansıyan bir davada Kavak köyünden bazı kişilerin 10 ylldır ahalisi tarafından terk edilmiş harap vaziyette olan Dinorna arazisinde (Foto 2) ziraat yaptıkları ve buradan elde ettikleri ürün karş1llğı vergi vermedikleri ifade edilmiştir (KŞS 23, 70/1 ve 90/1). Davaya konu olması bu sahada zirai üretimin devam ettiğini ve edebileceğine dair ipucu şeklinde değerlendirilebilir. 
Konya çevresinde Kavak köyü kadar dikkat çekici olmasa da sahada bulunan diğer iskân merkezlerinin toplulaştığına ilişkin birtakım bilgiler elde etmek mümkün olmuştur. Örneğin Başara köyü gelirlerinin vakfa tahsis edilmesi dolayısı ile çevresinde bulunan köyler için bir cazibe merkezî olmuştur. Arşiv kayıtlarında en son 1761 yılında mevcudiyeti tespit edilen Çeltek ve son kayıt tarihi 1739 olan Dilkemi köyleri ahalisinin Başara köyüne geldiği arazi araştırmaları esnasında öğrenilmiştir (İbrahim Özkay'dan alınan sözlü bilgi) (Foto 3). XVI. yüzyıl kaynaklarında görülmeyen Kızılören köyü 13 hane konar-göçerin burada toplanması sonucu ortaya çıktığı bilgisi yerel halk tarafindan ifade edilmiştir. Benzer şekilde Küçükköy isimli yerleşme de Hayıroğlanı ve Niğde tarafindan gelenlerin meskûn olduğu bir merkez olarak karşımıza çıkmaktadır.

\section{Foto 2. Terk Edilmiş Dinorna Köyü Sit Alanı $\quad$ Foto 3.Terk Edilmiş Çeltek Köyü Mezarlı̆ğ}
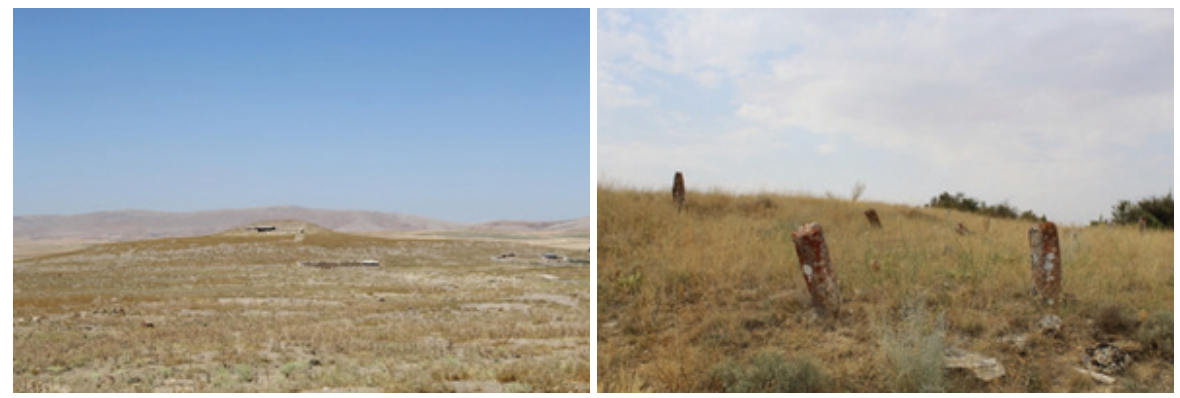

Köylülerin toplulaşmasının güvenlik gerekçesi ile devlet eliyle gerçekleştirildiği de görülmektedir. Bu tür bir olay Konya çevresi ile ilgili olmakla birlikte Manisa Şer'iye Sicili'nde rastlanmıştır. Burada yer alan kayda göre Esbkeşan mukataası köylerinden Karaman eyaleti dahilinde Eski İl kazasına bağlı Muradca, İnegaziler, Anla(?), Gine(?) ve Bağluca karyeleri ana yol üzerinde bulunmaktadır. Söz konusu köylerde 15-20 hane yaşaması hasebiyle levendat eşkıyasından kendilerini koruyamamışlardır. Bu nedenle köylülerin tamam1nın Bağluca Derbendi’nde toplanarak derbentçi kaydedilmelerine, buradan geçen hacıları ve yolcuları korumalarına karar verilmiştir. Ayrıca adı geçen köylerden dağılanların da Bağluca Derbendi’ne toplanması özellikle belirtilmiştir (MŞS 214,JPEG no 61/2).

Salgın hastalıklar (veba, sıtma yöresel tabirle ölet) nedeniyle Manisa çevresinde birtakım iskân merkezlerinin göç ettiği görülebilmektedir. Osmancalı köyü, geçmişte Çardakalanı mevkiinde iken salgın hastalıktan kaçan halkı, 
şimdiki yerinde köyü yeniden kurmuşlardır. Ayrıca Kartallar köyünde yaşayanlar çetelerden kurtulmak için Yukarıköy isimli mevkide yaşayanlar da salgin hastalık nedeniyle Osmancalı köyüne gelip yerleşmişlerdir. Bağyolu köyü de bugün Kovanca mevki adı verilen yerde iken salgın hastalıktan dolayı yok olmuştur. Bu köyden sadece bir kadın salgın hastalıktan kurtularak Bergama Örtülü köyüne göçmüştür (Feridun Yılmaz’dan alınan sözlü bilgi) (Harita 4).

Harita 4. Manisa Çevresi Osmancalı ve Băgyolu Köylerinde Toplulaşma

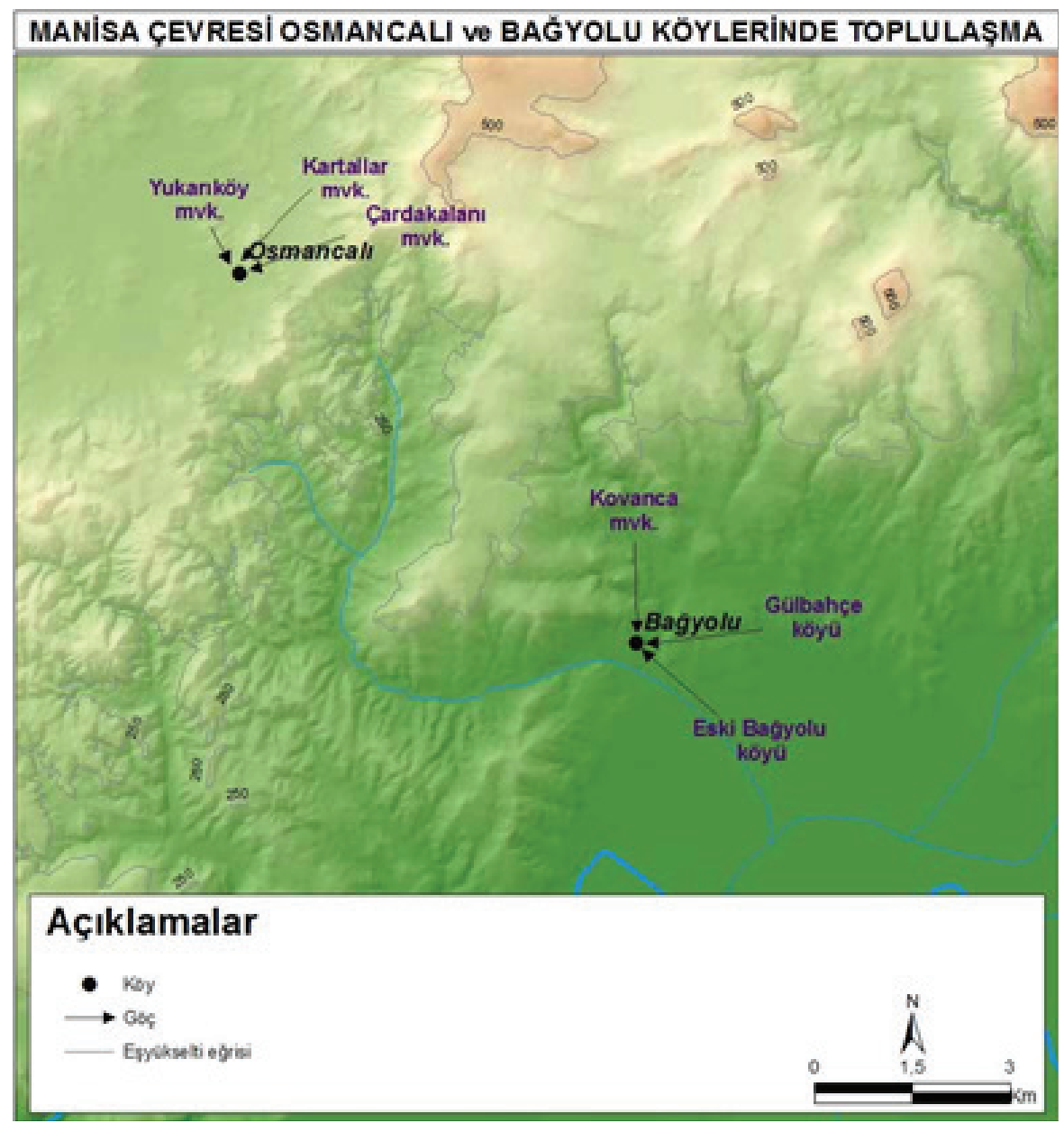

Salgın hastalıkların dışında Manisa çevresinde edinilen sözlü bilgilerden çeşitli toplulaşma örneklerinden söz etmek mümkündür. Sakallı yedi farklı iskân merkezînden (Dedeler, Fırıntepe, Tepişköy/Kasımlı, Bektaşlar, Paylukköyü, Katrancık) gelen konar-göçerlerin kurduğu bir yerleşmedir (Hasan 
Keskin'den alınan sözlü bilgi). Gümülcelü, konar-göçer grupların (Sazak obası, Çapar obası, Abnalılar obası, Çamlıba ve Resuller; Hoşçalar, Bozcalar ve Çaparlar isimli yörük cemaatleri ile Koldere köyünün) birleşimiyle kurulan köyler arasındadır. Seyitoba ve Bahadırlı köylerini Memiler ve Sindel köyünden göçüp gelenler kurmuştur (Şerif Ahmet Yılmaz'dan alınan sözlü bilgi) (Foto 4). Maldan köyü sakinleri yerleşmelerinin 400 yıl tarihi olduğunu ifade ettikten sonra Tepeköy, Gedikköy, Kocaköy ve Sarıkayalar isimli dört köyün burada toplandığını belirtmişlerdir (Mehmet Bilgin'den alınan sözlü bilgi).

\section{Foto 4. Sindel Köyü Harabesi}

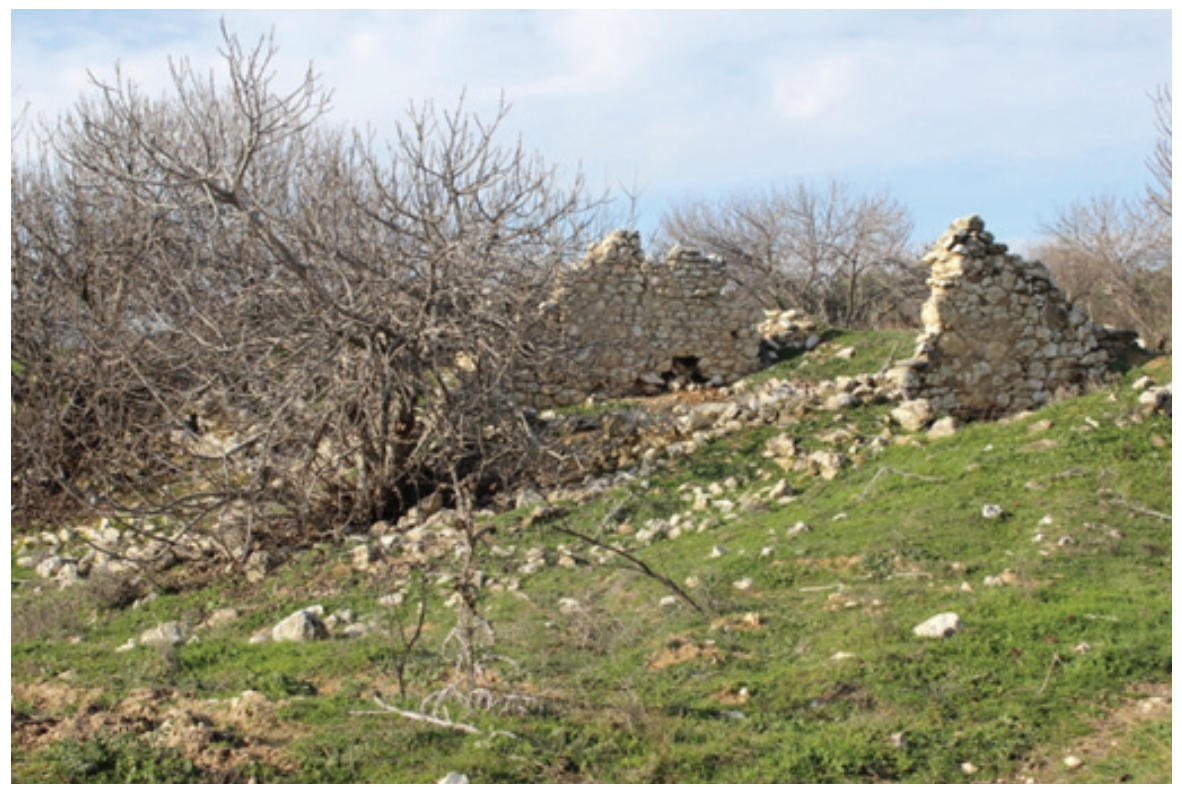

Osmanlı döneminde göçler siyasi, sosyal ve ekonomik faktörlerin yanında devlet görevlilerinin zulmünden, eşkıyalık faaliyetlerinden ve adaletin sağlanamamas1 gibi hususlardan meydana geliyordu. 1764 senesinde Anadolu'nun orta koluna (Üsküdar'dan başlayıp Tokat, Malatya, Diyarbakır, Nusaybin ve Kerkük üzerinden devam eden Bağdat-Basra yolu) gönderilen göçün men edilmesi fermanında özellikle valiler kendilerine tahsis edilen has, hazeriye ve diğer gelirleri ile yetinmeleri konularında uyarılmışlardır. Valilerin dışında taşrada görev yapan kadılar ve naiplerin rüşvete karışmaları, özellikle mahkemede görülen davalarda zulüm görmüş haklı kişilerin aleyhine sonuçlar çıkararak onlardan mahsul def' adı altında para almaktaydılar. Adaletin kırsal 
alanlarda tesis edilememesi ve kanun dışı paraların toplanması gibi durumlar göçün itici sebepleri olarak değerlendirilebilir. Ayrıca Anadolu ve Rumeli’den bir şekilde İstanbul'a ulaşan kasaba ve köy halkı, yeniçeri odabaşı ve oda bekçilerine dayanarak, aldıkları mektuplar ile bölgelerine döndüklerinde "biz İstanbul'a varub yeniçeri olduk diye tebdil-i kıyafet" taşrada yeniçerilik iddiasında bulunuyorlardı. Köylüler ise yüksek faizlerle borçlanarak ellerindeki tarım arazilerini bir hüccet çıkartıp satarak borçlarını ödemeye çalışıyorlardı. $\mathrm{Bu}$ durumda topraksız kalan köylüler çareyi göç etmekte buluyorlardı (Özkaya, 1981-1982: 172-173).

Ülke sathında yaşanan göçler neticesinde tarımsal üretim gerilemiş, vergi kalemleri düşmüş ve bu durum karşısında devlet göçü önlemeye ilişkin 1719 tarihinde birtakım tedbirler almıştır: 1) Göç etmek isteyenler subaylar tarafindan engellenecek, yakalananlar hapsedilecek, 2) Gizlice kaçmayı başaranlar diğer bölgelerde yakalanarak yerine geri döndürülecek, 3) Göç edenler cezalandırılarak diğerlerinin göçü engellenecek, halk adaletle yönetilecek 4) $\mathrm{Bu}$ kurallar çerçevesinde hareket edilecek aksine hareket cezalandırılacaktır. Alınan bu tedbirlere rağmen göçün önü alınamamıştır. Nitekim 1740 yılında çıkarılan adalet fermanında şu hususlar dikkati çekmektedir: 1) Zabitler, ayanlar, kadılar, naipler aşar muhassılları zalimlere yardım etmeyecek, halka yardımcı olarak onları koruyacaktır. 2) Emr-i şerif olmadan vilayet harcı ile vergiler halka yüklenmeyecektir. 3) Çeşitli bahanelerle halka zarar verilmeyecektir 4) Bu durumlara uyulup uyulmadığı gizli ve açıktan teftiş edilecek, ihmali olanlar cezalandırılacaktır. 5) Haksız yere hapse atılanlar ve zincire vurulanlar araştırılarak ortaya konulacaktır. 6) Valiler hazeriyeleri ile yetinmezler, zabitler, ayanlar aç gözlülükleri nedeniyle haksız vergi toplarlar ve halka zulmederlerse cezalandırılacaktır. 7) Şayet kanun dışı avarız ve diğer vergiler toplanırsa tespit ve defter edilerek mübaşire teslim edilecektir (Özkaya, 1981-1982: 174-175). Bu maddelerde açık bir şekilde görüldüğü üzere devlet merkezînin adaletnameler vasıtasıla en çok üzerinde durduğu hususlar ehl-i örfün ve diğer önde gelen kişilerin halka zulüm ederek haksız vergi toplaması neticesinde göçe neden olmalarıdır. Adalet üzere hükmedilmesi, haksız vergi toplanmaması, halkın korunup kollanması, mevcut haksızlıkların giderilmesi ve ihmali olanların cezalandırılması şeklinde uyarılar ile taşrada göçün itici sebepleri ortadan kaldırılmaya çalış1lmıştır. Ancak bu uyarılar çok da işe yaramamış, halk bir şekilde göç kervanına katılmaya devam etmiş ve merkezî idare de adaletname göndermeyi sürdürmüştür.

Gerçekleşen göçler neticesinde yerelde ve ülke sathında birtakım sorunlar baş göstermiştir: 1) Has, vakıf, zeamet ve timar gelirleri zarar görmüş ve noksanlıklar ortaya çıkmıştır. 2) Göç edenlerin üzerine düşen vergiler geride ka- 
lanlara yüklenmiş ve göçe katılmayan halk perişan olmuştur. 3) Göç edilen yerlerde kıtlık, yangın gibi hususlar ortaya çıkmıştır. Adaletnameler, uyarılar ve tedbirlere rağmen kırsal alanda göçün itici faktörleri ortadan kaldırılamamış ve önüne geçilememiştir. 1789 Mart ayı sonunda Anadolu'nun săg koluna yazılan adalet fermanında, kadılar ve naiplerin, şehir kethüdaları ve diğer görevliler ile anlaşarak savaş için araba, deve katır ve bunun gibi istekleri bir kişiye iltizam suretiyle verdikleri anlaşılmıştır. İltizam yoluyla bunu alan kişilerin iki katı bir değeri reayadan zorla toplayarak şehir kethüdaları ve mübaşirleri ile aralarında paylaştıkları, kadıların ve naiplerin de "harc-1 tekalif-i seferiyye" adı ile akçe aldıkları anlaşılmaktadır (Özkaya, 1981-1982: 183-191). 


\section{SONUÇ VE DEĞERLENDİRME}

Yapılan arazi araştırmaları, arşiv taraması ve ilgili literatür incelemeleri neticesinde kırsalda meydana gelen göçlerin sebepleri hakkında bazı değerlendirmelerde bulunmak mümkündür. Osmanlı Anadolu'sunda göçlerin başlıca sebepleri doğal afetler, salgın hastalıklar, eşkıyalık faaliyetleri, ve vergi baskısı olarak değerlendirilebilir. Söz konusu bu durumların etkisiyle kırsalda yaşayan halk zorunlu olarak göçe yönelmiştir. Nitekim daha XVI. yüzy1l içinde tahrir defterlerine gerek Konya ve gerekse Manisa çevrelerinde çeşitli nedenlerle meydana gelen göçler yansımıştır.

Deprem, sel, taşkın gibi doğal afetler Anadolu kırsalında insanları göçe sevk eden faktörler arasındadır. Manisa çevresinde meydana gelen depremler insanların canına ve malına zarar vererek göç etmelerine yol açmıştır. Bu durum arşiv vesikalarına yansıdığı gibi arazi çalışmaları sırasında yapılan görüşmelerde de yerel halkın hafızasında hala canlılığını koruduğu görülmüştür.

Manisa Ovası'nda Gediz Nehri başta olmak üzere akarsuların taşkınlar yapması ve yatak değiştirmesi köylülerin yerleşmelerinin yanında tarım alanlarının çakıl ve kumlarla kaplanmasına, sazlık ve bataklık hale gelmesine yol açarak kırsal kesimdeki insanları göçe mecbur etmiştir. Konya çevresinde ise şiddetli yağışlara bağlı olarak sellerin oluştuğu ve Konya Ovası'nda göllerin ortaya çıktığı ve mevcut göllerin de alanlarını genişleterek göçü tetiklediği anlaşılmaktadır.

Ayrıca veba ve sıtma başta olmak üzere salgın hastalıklar tüm Osmanlı ülkesinde olduğu gibi özellikle Manisa çevresinde de eksik olmamış gibidir. Zira farklı zamanlara ait kaynaklardan elde edilen bilgi ve bulgulara göre salgın hastalıklar, XVI. yüzyıldan XX. yüzyıla değin kırsal ve şehirsel alanlarda insanların karşılaştığı en önemli problemler arasındadır. Özellikle Manisa çevresinde veba ve sıtmanın yaygın olduğu arşiv vesikalarından ve arazi çalışmalarında sıklıkla karşılaşılan durumlardır. Bu sahadaki insanlar bazen köylerinin yerini değiştirirken bazen de topyekûn göçe katılarak başka köylere göç etmişlerdir.

Manisa ve Konya çevreleri konar-göçerlerin yerleşmek üzere karar kıldığ sahalar olduğu dikkati çekmektedir. Özellikle Manisa çevresine Anadolu'nun muhtelif bölgelerinden (Anadolu, Maraş, Sivas, Erzurum ve Halep eyaletlerinden) konar-göçerlerin gelip mal ve mülk edinerek burada yaşamaya karar vermeleri açısından dikkate değerdir. Konya şehri ve çevresindeki köylerin 
ise Tuz Gölü'nün güney kesimlerinde bulunan Atçekenler için bir cazibe merkezî olduğu görülmektedir. Atçekenlerin şehirdeki mahallelere yerleşmeleri ayrıca dikkate değer bir durumdur.

Özellikle savaşlar, siyasi, sosyal ve iktisadi buhranlar tarihi süreçte zorunlu göçü tetikleyen başlıca unsurlardır. Celâli ve çeşitli eşkıya grupları dışında devlet ricalinin adamları vasıtasıyla "devre çıkıp" halkın malına ve canına zarar vermesi araştırılan dönemin ayrı bir veçhesini oluşturmaktadır. Söz konusu bu durumun her iki araştırma çevresi için ortak bir özelliği olarak karşımıza çıkmaktadır. Devletin otoritesini temsil eden ve adaletle hükmetmek üzere görevlendirilen sancakbeyleri, muhassıllar, kadılar, timarlı sipahiler, voyvodalar vs. zaman zaman eşkıyalar ve Celâlileri aratmayacak eylemlerde bulunmuşlardır. Tüm bunlar karşısında kıt kanaat geçinen ve geleneksel tarım yöntemleri ile üretme, vergisini devlete ve onun temsilcilerine verme gayretinde olan halk, bu işlerden en fazla zararlı çıkan mazlum taraf olmuştur. Avarız vergisinin XVII. yüzyıldan itibaren devamlı bir vergi kalemi haline gelmesi kırsal alanda yaşayan köylülerin üzerindeki yükü iyice artırmıştır. Onlar canını ve malını kurtarmak için bazı durumlarda da mallarından vazgeçerek çiftini çubuğunu bırakarak dağllk, ormanlık alanlara ve güvenli gördükleri şehir, kasaba ve köylere göç etmek suretiyle yaşam mücadelelerine devam etmişlerdir. Konya çevresinde görüldüğü üzere merkezî ve güvenli köyler çevredeki köylüler için birer cazibe merkezî haline gelmiştir. Örneğin Kavak köyü çevresinde bulunan XVI. yüzyılda mevcudiyetini bildiğimiz 7 köy, topyekûn göç ederek Kavak köyünde toplanmıştır.

Avarız vergisinden muaf olan Manisa şehri çevresindeki köylü halk için bir cazibe merkezî haline gelmiştir. Dönem kaynaklarına yansıdığı üzere insanlar Manisa şehrine göç ederek yerleşmişlerdir. Konya çevresinde ise bir vakıf köyü olan Başara'nın bir cazibe merkezî olabildiği görülmektedir. Yakınında bulunan köylerin halkı topyekün Başara'ya gelerek vergiden kurtulmak istemişlerdir.

Çorum Şer'iye Sicilleri'nden 1595-1596 tarihli bir defter üzerine yaptığ1 araştırmasında S. Faroqhi, vergi mükelleflerinin etkinliklerini ele alarak, vergilerde meydana gelen artış ile birlikte vergi toplanmasındaki şiddette meydana gelen artı̧ıı, kırsalda yaşayan birçok köylünün gözünde mevcut hayatlarının çekiciliğini ortadan kaldırdığı tespitini yapmıştır (Faroqhi, 2008: 309). Nitekim gerek Faroqhi tarafindan Çorum özelinde yapılan inceleme gerekse bu çalışma kapsamında farklı arşiv kaynaklarından elde edilen belge ve bulgular, halkın yeni vergilerden ve haksız taleplerden oldukça şikayetçi olduğunu ve en nihayetinde göçe yöneldiğini göstermektedir. Bazen bireysel 
olarak gerçekleşen bu göçler bazen toplu bir halde de oluşabiliyordu. Ancak bireysel olarak göçlerin de geride kalanların sırtındaki vergi yükünü artırması ya giden kişin geri döndürülmesi çabası ile ya da göç edenlerin arkasından kalanların da bu göç sürecine dahil olmalarını icbar ediyordu.

Ana ulaşım ağ1 üzerinde bulunmak yerleşmenin kuruluş ve gelişmesinde önemli bir unsur iken eşkıyalığın fazla olduğu dönemlerde insanları göç etmeye zorlayan bir husus olduğu Konya çevresinde (Konya'dan Isparta ve Akşehir istikametine devam eden kervan yolu güzergâhında) görülebilmektedir. Yol üzerindeki yerleşmelerin halkı köylerini tamamen terk ederek 2-3 kilometre ana ulaşım ağından uzaklaştığı, vadi içlerine çekildiği anlaşılmaktadır.

Tüm bu durumlar (ve belki elimizde belge bulunmadığından ya da bir şekilde) ulaşamadığımız doğal afet sebepleriyle tarihi süreçte insanları göçe zorlayan bir takım olumsuzluklar arasındaki, yerini almıştır. İşte söz konusu bu durumlar halkı yerinden yurdundan istemese de bir umut peşinde sürüklenmeye, başka yerleşmelere, bazen kırsal alana, bazen şehirlere göç etmeye mahkûm etmiştir.

Araştırılan zaman diliminde yaşanan göçler kırdan şehre olabildiği gibi belki ondan fazla bir kısmı kırsalın kendi içerisinde cereyan etmiştir. Arşiv vesikaları ve arazi araştırmaları sırasında elde edilen bilgiler bu duruma dair önemli ipuçları niteliğ̈indedir. Kırsalda meydana gelen göçler yukarıda ifade edilen çeşitli sebeplere bağlı olarak ortaya çıkan durumlarda merkezî, güvenlikli ve kalabalık köylere doğru olmuştur. Başta ekonomik ve güvenlik faktörlerinin etkisiyle gerçekleşen kırsal alandaki göçler neticesinde kırsal iskân merkezleri yer yer toplulaşmıştır. Meydana gelen toplu göçler, bir kısım köylerin ortadan kalkmasına yol açarken bir kısım yerleşmelerin de devamlılığında göçmenler önemli katkılar sağlamıştır. 


\section{KAYNAKLAR}

\section{Arşiv vesikaları:}

Başbakanlık Osmanlı Arşivi (BAO TD): BOA TD 115/39a, 387; BOA TD 165: 66-67.

Konya Kazası Hurufat Defteri No: 1107.

Konya Kazas1 Nüfus Defteri No: 3447.

Konya Şer'iye Sicili (KŞS): KŞS 9; KŞS 12, 156/2; KŞS 12, KŞS 16, KŞS 20; 174/3; KŞS 23, 7/1; KŞS 23, 70/1 ve 90/1; KŞS 25, 255/1; KŞS 26, 71/2; KŞS 31, 48/3; KŞS 5, 19/2; KŞS 55, 155/1; KŞS 64, 84/2; KŞS. 48, 159/1. KŞS 205/3.

Manisa Şer'iye Sicili (MŞS): MŞS 214,JPEG no 61/2; MŞS 41,152/1; MŞS $49,161 / 3$.

Tapu Kadastro Kuyud-1 Kadime Arşivi (TK KKA): TK KKA 104.

\section{Araştırma eserler:}

Akdağ, M. (1964). "Büyük Kaçgunluk”, Ankara Üniversitesi Dil ve TarihCoğrafya Fakültesi Tarih Araștırmaları Dergisi, 2(2), s. 1-51.

(1999). Türk Halkının Dirlik ve Düzenlik Kavgası (Celâli İsyanlarl), Ankara: Barış Yayınevi.

Aktepe, M. (1958). "XVIII. Asrın İlk Yarısında İstanbul'un Nüfus Meselesine Dair Bazı Vesikalar”, İstanbul Üniversitesi Edebiyat Fakültesi Tarih Dergisi, IX(13), s. 1-30.

Altınay, A. R. (1987). Onuncu Asrı Hicride İstanbul Hayatı, İstanbul: Enderun Kitabevi.

Ambraseys, N. N. ve Finkel, C. F. (2006). Türkiye'de ve Komşu Bölgelerde Sismik Etkinlikler Bir Taribsel İnceleme 1500-1800, Ankara:TÜBİTAK Yayınları.

Arslan, H. (2001). 16. Yüzyıl Osmanlı Toplumunda Yönetim, Nüfus, İskan, Gö̧̧ ve Sürgün, İstanbul: Kaknüs Yayınlar1.

Barkan, Ö. L. (1950). “Osmanlı İmparatorluğu’nda Bir İskan ve Kolonizasyon Metodu Olarak Sürgünler”, İstanbul Üniversitesi İktisat Fakültesi Mecmuasi, 11(1-4), s. 524-569.

Barkan, Ö. L. ve Meriçli, E. (1988). Hüdavendigar Livası Tahrir Defterleri I, Ankara: Türk Tarih Kurumu Yayınları. 
Braudel, F. (1993). II. Felipe Döneminde Akdeniz ve Akdeniz Dünyası I-II, Ankara: İmge Kitabevi.

Çağatay, N. (1947). "Osmanlı İmparatorluğunda Reayadan Alınan Vergi ve Resimler”, Ankara Üniversitesi Dil ve Tarih-Coğrafya Fakültesi Dergisi, 5(5), s. 483-511.

Çağlayan, S. (2006). "Göç Kuramları, Göç ve Göçmen İlişkisi”, Muğla Üniversitesi Sosyal Bilimler Enstitüsü Dergisi, (17), s. 67-91.

Demir, A. (2007). 16. Yüzyılda Samsun-Ayıntab Hattı Boyunca Yerleşme, Nüfus ve Ekonomik Yapı, (Yayınlanmamı̧ Doktora Tezi), Ankara Üniversitesi Sosyal Bilimler Enstitüsü, Ankara.

Demir, A. (2009). "16. Yüzyılın İlk Yarısında Diyarbakır Şehir Demografisine Göçlerin Etkisi”, Bilig, (28), s. 15-28.

(2011). “XVI. Yüzyıl Anadolu’sunda Dı̧̧ Göçler: Şarkiyan”, Karadeniz Araștırmaları, (28), s. 51-66.

Demirtaş, M. (2004). "XVI. Yüzyılda Meydana Gelen Tabii Afetlerin İstanbul'un Sosyal ve Ekonomik Hayatına Etkilerine Dair Bazı Misaller”, Atatürk Üniversitesi Sosyal Bilimler Enstitüsü Dergisi, 4(2), s. 37-50.

(2011). “Osmanlıya Gelen Kırım ve Kafkasya Göçmenlerinin Sorunları”, Bilig, Say1 57, s. 17-44.

(2017). “XIX. Yüzyılda İstanbul'a Göçü Önlemek İçin Alınan Tedbirler: Men-i Mürûr Uygulaması ve Karşılaşılan Güçlükler”, Belleten, Cilt: LXXIII-Say1: 268, s. 739-754.

2017. “XIX. Yüzyılın İlk Yarısında İstanbul'da Kamu Düzenini Bozan Gruplara Karşı Yürütülen Mücadele”, Belleten, Cilt:LXXXISay1:291, s. 481-524.

Emecen, F. M. (1989). XVI. Asırda Manisa Kazası, Ankara: Türk Tarih Kurumu Yayınları.

Emecen, M.(2003)."Manisa/Tarih”, Türkiye Diyanet Vakfi İslam Ansiklopedisi, İstanbul: Türkiye Diyanet Vakfi Yayınları, C. 27, s. 577-583.

Erdoğan Özünlü, E. ve Gümüşçü, O. (2016). “Osmanlı İmparatorluğu'nda İç Göç Aktörleri Olarak Çift-Bozanlar”, Amme İdaresi Dergisi, 49(1), s. 29-56.

Faroqhi, S. (1993). Osmanlida Kentler ve Kentliler, İstanbul: Tarih Vakfi Yurt Yayınları. 
(1998). "Migration into Eighteenth-Century Greater İstanbul as Reflected in the Kadi Registers of Eyüp”, Turcica, (30), s. 163-183.

(2016). "Osmanlı Nüfusu”, Türkiye Taribi 1453-1603 içinde İstanbul: Kitap Yayınevi, s. 437-489.

Genç, M. (2007). “Osmanlılar/İktisadi ve Ticari Yapı”, Türkiye Diyanet Vakfi İslam Ansiklopedisi. İstanbul: Türkiye Diyanet Vakfi Yayınları, C. 33, s. 525332.

Gökçen, İ. (1946). 16. ve 17. Asır Sicillerine Göre Saruban'da Yürük ve Türkmenler, Manisa: Manisa Halkevi Yayınları.

Güler, İ. (2000). “XVIII. Yüzyılda Osmanlı Devleti'nde Nüfus Hareketleri Olarak İç Göçler”, İstanbul Üniversitesi Edebiyat Fakültesi Tarih Dergisi, 1995-2000 Prof. Dr. Fikret Işıltan Hatıra Sayısı, (36), s. 155-211.

Gümüşçü, O. (2001). XVI. Yüzyıl Larende (Karaman) Kazasında Yerleşme ve Nüfus, Ankara: Türk Tarih Kurumu Yayınları.

(2004). "Internal Migrations in Sixteenth Century Anatolia", Journal of Historical Geography, 30(2), s. 231-248.

Gümüşçü, O., Erdoğan Özünlü, E. ve Demir, A. (2016). Türkiye’nin İskan Taribinde Önemli Bir Problem: Kaybolan Yerleşmeler, Ankara: TÜBİTAK.

İpek, N. (1991). “Kafkaslar'dan Anadolu'ya Göçler (1877-1900)”, Ondokuz Mayıs Üniversitesi Eğitim Fakültesi Dergisi, Sayı 6, s. 97-134.

(1991). "Kafkaslardaki Nüfus Hareketleri”, Türkiyat Mecmuası, Say1 20, s. 273-313.

(1999). Rumeliden Anadolu’ya Türk Göleri, Ankara: Türk Tarih Kurumu Yayınları. Yayınlar1.

(2006). Imparatorluktan Ulus Devlete Gö̧ler, Trabzon: Sarender

(2014). “Kaynakların Dilinde Göç Kavramı”, Karadeniz İncelemeleri Dergisi, Sayı 17, s. 9-20.

Karadeniz, H. B. (1995). Atçeken Oymakları (1500-1642), (Yayınlanmamış Doktora Tezi). Erciyes Üniversitesi Sosyal Bilimler Enstitüsü, Kayseri.

Karpat, K. (2003). Osmanl Nüfusu (1830-1914) Demografik ve Sosyal Özellikleri, İstanbul: Tarih Vakfi Yurt Yayınları.

(2010). Osmanlidan Günümüze Etnik yapılanma ve Göcler, İstanbul: Timaş Yayınları. 
(2015). “Önsöz” (Der. M. M. Erdoğan ve A. Kaya) Türkiye’nin Gö Taribi 14. Yüzyıldan 21. Yüzyıla Türkiye’ye Göcler içinde (XXIII-XL.), İstanbul: İstanbul Bilgi Üniversitesi Yayınları.

Kenanoğlu, M. M. (2013). "Vergi”, Türkiye Diyanet Vakfi İlam Ansiklopedisi. İstanbul: Türkiye Diyanet Vakfı Yayınları, C. 43, s. 52-58.

Küpeli, Ö. (2011). "Klasik Tahrirden Avarız Tahririne Geçiş Sürecinde Tipik Bir Örnek: 1604 Tarihli Manyas Kazası Avarız Defteri”, Belgeler, XXXII(36), s. 113-199.

McCharty, J. (2014). Ölüm ve Sürgün, Ankara: Türk Tarih Kurumu Yayınları,

Mete, Z. (2011). "Sur Dişı İstanbul'unda İskanın Tarihi Seyri (XV-XVIII. Yüzy1llar)”, Tarkya Üniversitesi Edebiyat Fakültesi Dergisi, 1(2), s. 57-84.

Özdeğer, H. (1988). Onaltıncı Asırda Ayıntab Livası, İstanbul: İstanbul Üniversitesi Yayınları.

Özdemir, R. (1993). "Avarız ve Gerçek-Hane Sayılarının Demografik Tahminlerde Kullanılması Üzerine Bazı Bilgiler”, X. Türk Tarib Kongresi, sunulmus bildiri, Ankara: Türk Tarih Kurumu Yayınları, C. IV, s. 1581-1613

Özel, O. (2000). "Avarız ve Cizye Defterleri”, Osmanlı Devleti’nde Bilgi ve Ístatistik içinde, Ankara: Devlet İstatistik Enstitüsü Yayını, s. 35-50.

Özkaya, Y. (1981). “Osmanlı İmparatorluğu'nda XVIII. Yüzyılda Göç Sorunu”, Ankara Üniversitesi Dil ve Tarib-Coğrafya Fakültesi Tarih Araştırmalarn Dergisi, XIV(25), 171-211.

Pakalın, M.Z. (1993). Osmanlıca-Türkçe Ansiklopedik Lîgat (C. I-III), Ankara: Milli Ĕ̆itim Bakanlığı Basımevi.

Quataert, D. (2002). Osmanlı İmparatorluğu 1700-1922, İstanbul: İletişim Yayınları.

Sahillioğlu, H. (1991). “Avarı", Türkiye Diyanet Vakfi Íslam Ansiklopedisi, İstanbul: Türkiye Diyanet Vakfı Yayınları, C. 4, s. 108-109.

Satılmış, S. (2012). Aydın Vilayetinde Doğal Afetler (1850-1900), (Yayınlanmamış Doktora Tezi). Celal Bayar Üniversitesi Sosyal Bilimler Enstitüsü, Manisa.

Şahin, C. ve Sipahioğlu, Ş. (2007). Doğal Afetler ve Türkiye, Ankara: Gündüz Eğitim Yayıncılık.

Şeker, C. (2007). İstanbul Abkam ve Atik Şikayet Defterlerine Göre 18. Yüzyılda Istanbul'a Yönelik Göclerin Tasvir ve Tablili, (Yayınlanmamış YL Tezi), Marmara Üniversitesi Sosyal Bilimler Enstitüsü, İstanbul. 
Tabakoğlu, A. (1999). “Osmanlı İçtimai Yapısının Ana Hatları”, Osmanlı içinde, Ankara: Yeni Türkiye Yayınları, C. 4, 17-31.

Tekeli, İ. (2008a). "Göç Teorileri ve Politikaları Arasındaki İlişkiler”, Gö̧̧ ve Ötesi içinde, Ankara: Tarih Vakfi Yurt Yayınları, s. 18-41.

(2008b). “Türkiye'nin Göç Tarihindeki Değişik Kategoriler”, Gö̧ ve Ötesi içinde, Ankara: Tarih Vakfi Yurt Yayınları, s. 42-67.

(2008c). "Osmanlı İmparatorluğu’ndan Günümüze Nüfusun $\mathrm{Zo}_{\mathrm{o}}$ runlu Yer Değiştirmesi ve İskân Sorunu”, Gö̧̧ ve Ötesi içinde (141-170), Ankara: Tarih Vakfı Yurt Yayınları.

(2011). “Yerleşme Yapıları ve Göç Araştırmaları”, Anadolu'da Yerleşme Sistemi ve Yerlę̧me Taribleri içinde, Ankara: Tarih Vakfi Yurt Yayınlar1, s. 162-177.

Tızlak, F. (2010). “XIX. Yüzyılın İlk Yarısında Isparta Kazasının İdari Durumu ve Avarız Hane Kayıtlarının Isparta'nın Nüfus Tahminlerinde Kullanilamayacağına Dair Bir Deneme", Süleyman Demirel Üniversitesi Sosyal Bilimler Dergisi, Prof. Dr. Bayram Kodaman'a Armağan Özel Sayısı, s. 114-123.

Uluçay, M. Ç. (1944). XVII. Yüzyılda Saruban'da Eşkıyalık ve Halk Hareketleri, Manisa: CHP Manisa Halk Evi Yayınları.

Ünal,M.A. (1997). “1646 (1056) Tarihli Harput Kazası Avarız Defteri”, Ege Üniversitesi Tarih Incelemeleri Dergisi, 12, 9-73.

Yakar, M. (2009). Emirdağ İlçesi Kırsalında Göçün Etkileri, Sorunları ve Çözüm Önerileri, (Yayınlanmamış Doktora Tezi), Afyon Kocatepe Üniversitesi Sosyal Bilimler Enstitüsü, Afyonkarahisar.

Yiğit, İ. (2017). "Iskândaki Kararsızlık: Doğal Afetler ve Kaybolan Yerleşmeler (XVI-XX. Yüzyıl Manisa-Konya Çevresi Örneği)”, Hacettepe Üniversitesi Türkiyat Araștırmaları, (26), 329-364.

(2018). “Tarihi Göç Çalışmalarında Bir Veri Kaynağı Olarak Mezar Taşları”, XVIII. Türk Tarib Kongresi (01.10.2018 -05.10.2018), Ankara.

(2018). “Tarihi Göç Çalışmalarında Osmanlı Dönemi İstatistiki Kaynakları”, TÜCAUM 30. Yıl Uluslararası Coğrafya Sempozyumu, Ankara, s. 641-650.

Yiğit, İ. ve Gümüşçü, O. (2016). "Manisa ve Çevresinde Salgın Hastalıkların Iskâna Etkisi (XVI-XX. yy.) (379-391)”, TÜCAUM Uluslararası Coğrafya Sempozyumu Bildirileri, Ankara, s. 379-391. 
